\title{
O Brasil no contexto do narcotráfico internacional
}

\author{
ARGEMIRO PROCÓPIOFILHO* \\ ALCIDES COSTA VAZ**
}

\section{Considerações preliminares}

O presente texto apresenta alguns dos resultados da pesquisa “Dimensões

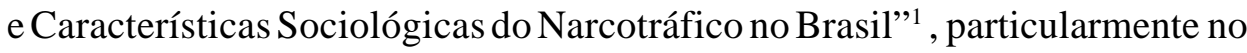
que se refere à caracterização do fenômeno no contexto brasileiro. Trata-se de um esforço inicial no sentido de dimensionar e caracterizar o narcotráfico em suas mais importantes tendências e manifestações na sociedade brasileira e de identificar as principais formas de sua vinculação ao narcotráfico interna-cional.

O tema "narcotráfico" é relativamente novo tanto na agenda política quanto como objeto de estudo nas universidades brasileiras. Isso, porém, não significa que o mesmo não se tenha constituído fonte de preocupação e não tenha despertado a atenção das autoridades governamentais e da própria sociedade em períodos anteriores. Na verdade, existem leis voltadas para a questão do narcotráfico desde $1976 .{ }^{2}$ É igualmente verdadeiro que apenas nos últimos anos, em razão de seu agravamento, de suas origens, manifestações e implicações, tanto no plano doméstico como no das relações internacionais, o narcotráfico passou a ser preocupação de fato para a sociedade e para o governo.

A maior atenção para com as dimensões dos problemas relacionados ao narcotráfico associa-se a três fatores básicos. Primeiramente, a relevância política e econômica que o tema assumiu no cenário internacional e regional. As drogas, afetando todos os países e projetando-se no território brasileiro, levam importantes parceiros, particularmente os Estados Unidos e a União Européia, a desenvolverem políticas em relação às quais tanto o governo como diferentes

Rev. Bras. Polít. Int. 40 (1): 75-122 [1997].

* Professor titular do Departamento de Relações Internacionais da Universidade de Brasília. ** Professor assistente do Departamento de Relações Internacionais da Universidade de Brasília. 
segmentos da sociedade brasileira se viram instados a posicionar-se. Em segundo lugar, o narcotráfico associou-se e pôde nutrir-se das mudanças e dos problemas que acometem a sociedade brasileira, como por exemplo, o enfraquecimento do Estado, o aumento do desemprego, do subemprego com correspondente incremento e diversificação da economia informal em todo o país. Vale dizer, a deterioração da condição econômica e social de parte da população, a marginalização crescente de segmentos sociais no processo de desenvolvimento, o intenso crescimento dos centros urbanos, tudo isso se atrela às drogas e aos elevados índices de criminalidade. Por último, a incorporação de camadas populares ao mundo do consumo de drogas anteriormente reservado principalmente a pessoas das classes média e alta. Isso sem esquecer o translado do narcotráfico para as cidades de médio porteno interior dos Estados do Sudeste e do Centro-Sul do país. Não menos importante neste trabalho é o relato de fatos que testemunham a incapacidade ou inoperância do próprio Estado no cumprimento de muitas de suas funções básicas em matéria de prevenção e repressão, permitindo o alastramento da corrupção, disseminada nas esferas pública e privada.

A conjunção destes fatores continua a gerar condições propícias para a expansão do narcotráfico, fazendo com que o País deixe de ser apenas uma rota privilegiada do narcotráfico internacional, tal como tradicionalmente se fez acreditar. OBrasil processa, importa e exporta vários tipos de drogas. Tornou-se importante centro de produção e de consumo, além de fornecer novas drogas alternativas para os mercados interno e externo e de se ter constituído em mais uma peça da engenharia do crime do narcotráfico internacional. ${ }^{3}$ Assim, rapidamente cresce a importância do País no comércio internacional de drogas. Aumentam então, no cenário mundial, as expectativas quanto ao seu papel no enfrentamento do mesmo.

Desde 1993, a discussão sobre o tema do narcotráfico associou-se a outras questões igualmenteimportantes para a sociedade brasileira, como corrupção política, violência e criminalidade, governabilidade, papel das Forças Armadas, reformas do Estado, da economia e do sistema financeiro em geral. Aabrangência do debate sobre o narcotráfico resultante de sua vinculação com as questões acima referidas reflete sua complexidade orgânica na sociedade brasileira. Por outro lado, demonstra mudanças quanto à forma com que o próprio governo e a sociedade passaram a abordar o problema.

É importantelembrarque, tradicionalmente, nãoapenas onarcotráfico, como ouso de drogas em geral, foi tratadono Brasil em termos bastante elementares, ou seja, comouma questãodeordemlegalemédica. ${ }^{4}$ Em decorrência disso, as forças policiais, os tribunais e as instâncias ligadas à saúde acabaram tornando-se, por bom período, os principais -senão exclusivos-instrumentos do Estado para tratar dos problemas 
vinculados às drogas ilícitas. Alegislaçãobrasileira consagrou, nos anos setenta, este enfoque pautado na criminalização do consumo, dando pouca ênfaseà prevenção e à contenção do tráfico interno. Este enfoque perdurou até meados dos anos noventa. Praticamente inexistiuatéentão uma política governamental articulada encarando o tema em suas diferentes dimensões.

A este quadro de apatia por parte do Estado e da sociedade e aos fatores anteriormente mencionados, favorecedores da penetração e do crescimento do narcotráfico no Brasil, soma-se o pouco conhecimento disponível sobre o tema. Fora do domínio dos mecanismos de monitoramento e de repressão, vale dizer das estruturas policiais e de inteligência, com todas as limitações características, há pouca informação sistematizada para abastecer o processo de formulação de políticas e de tomada de decisões neste campo. São igualmente escassos, como se disse anteriormente, os estudos empreendidos nasuniversidades ou por organizações não-governamentais, embora se observe, a partir de 1994, maior interesse sobre o estudo do tema, talvez mesmo em razão de sua gravidade, no âmbito nacional e internacional, ede seus reflexos econômicos, políticos e sociais. ${ }^{5}$ Dada a deficiência de análise, tais reflexos não chegaram ainda a constituir aporte suficiente para a compreensão e definição de como encaminhar medidas e desenvolver mecanismos eficazes de resposta e de controle. Bons trabalhos começam a surgir, porém mais como esforço individual de pesquisadores do que como vontade expressa do Estado depromover eaprofundar esta temática complexa ecom desdobramentosimprevistos.

Embora tenha o Governo Federal, desde o Governo de Itamar Franco, e mais intensamente com Fernando Henrique Cardoso, se empenhado em revigorar mecanismos e conceber nova política frente à questão das drogas, passando a optar pela não exclusão de qualquer um dos instrumentos de Estado (principalmente as Forças Armadas) no enfrentamento da mesma, é notório o fato de que as respostas não chegam a configurar nenhum tipo de reversão ou alteração significativa do quadro do narcotráfico no Brasil. Isso porque, além do profundo enraizamento do fenômeno na sociedade e em segmentos do próprio aparelho estatal, recentes fatos acrescentaram dificuldades no trato da questão, como por exemplo as conseqüências das medidas de repressão adotadas nos países vizinhos e as novas estratégias dos narcotraficantes pautadasna descentralização deoperações, que serão exemplificadas neste trabalho. Ademais, aumentou sensivelmente o fluxo de bens e de pessoas através das fronteiras nacionais, em decorrência da abertura econômica e da integraçãono âmbito do MERCOSUL.As dificuldades enfrentadas pelo governo na implantação de um sistema de vigilância, sobretudo na Amazônia, capaz de conferir maior eficácia às ações preventivas e repressivas do Estado naquela região, não podemigualmente ser esquecidas. 
Em razão de se constituir em atividade de caráter transnacional e por seu enfrentamento ser objeto de políticas, inclusive de cooperação internacional, e ainda pelas peculiaridades do envolvimento do Brasil no fenômeno do tráfico internacional de drogas ilícitas, o estudo de sua sociologia, no caso brasileiro, necessita a contextualização da análise política de seus condicionantes regionais internos no âmbito das relações internacionais.

Neste trabalho estão envolvidos elementos de análise voltados para estes aspectos, incluindo estudo preliminar da estrutura e das tendências do narcotráfico, de suas estratégias, da resposta do Estado e da sociedade brasileira ao problema. São apresentadas numerosas exemplificações consideradas úteis para a compreensão das formas de globalização do fenômeno, vale dizer, as maneiras como se interligam o tráfico e o consumo de drogas no âmbito interno ao narcotráficointernacional.

Cumpre ressaltar que este conjunto entrelaçado de visões, realistas ou pessimistas, está refletido na literatura disponível. O levantamento realizado atéo presente pauta-se em matérias de fundo informativo de jornais, revistas, documentos de governos, livros e artigos. Os dados levantados, com poucas exceções, são aqueles transmitidos pela Polícia Federal e pela imprensa, sendo não raramente contrastantes. Observa-se que a bibliografia disponível reflete preocupação maior com a denúncia e menor com a análise. Denota freqüentemente percepção ditada por contundência de fatos que prendem a atenção do público mas nem sempre desenvolve análise abrangente e sistêmica do fenômeno.

Face às dimensões do universo das drogas não há dúvida de que a estrutura institucional e os mecanismos de prevenção, combate e repressão ao narcotráfico no Brasil são extremamente modestos frente à extensão do problema. A formulação e a execução da política de drogas são coordenadas pelo Ministério da Justiça, através do Conselho Federal de Entorpecentes (CONFEN). Este órgão, criado em 2 de setembro de 1980 e reformulado em 10 de maio de 1990, não foi operativo quando de sua criação. Reestruturado, o CONFEN busca desenvolver uma política mais consistente. Também sob autoridade do Ministério da Justiça está o Departamento de Polícia Federal (DPF), incumbido diretamente do combate ao tráfico de drogas, executado através da Divisão de Repressão de Entorpecentes(DRE), com o apoio da unidade de inteligência da própria Polícia Federal. O DPF, por sua vez, coordena a cooperação com as polícias civis e militares estaduais e, eventualmente, com as Forças Armadas. O envolvimento da Marinha, do Exército e da Aeronáutica na repressão ao narcotráfico esteve até 1995 restrito ao fornecimento de apoio logístico, material e informações, particularmente em áreas distantes e de fronteiras. Não se sabe por quanto tempo 
resistirãoàs pressões dos Estados Unidos daAmérica que querem seu envolvimento direto na guerra contra as drogas.

Cabe notar que por mais de vinte anos as ações de repressão dependiam integralmente dos recursos financeiros e materiais oferecidos pelos Estados Unidos. Até mesmo aqueles fundos disponíveis através do Programa das Nações Unidas para o Controle de Drogas (UNDCP) não puderam ser empregados por questões de ordem institucional. Somente a partir de 1994 o Governo Federal passou a alocar recursos orçamentários para este fim.

Além dos órgãos judiciários e da Polícia Federal, existe no país atuação específica do serviço de inteligência a cargo da Agência Brasileira de Inteligência. Ela atua sobretudo na produção de conhecimentos sobre o tráfico através do intercâmbio de informações com serviços de inteligência estrangeiros e com as forças policiais. Os órgãos de inteligência militares, por sua vez, não possuem atuação regular nessa questão. Com respeito às Forças Armadas, há um intenso debate sobre o seu envolvimento no combate direto ao narcotráfico. Em termos concretos, no entanto, este envolvimento direto passou a ocorrer com as Operações Rio I, em novembro de 1994, e II, em janeiro/fevereiro de 1995, efetuadas no Estado do Rio de Janeiro. Essas operações tiveram por objetivo restituir a presença e a atuação dos intrumentos do Estado em algumas áreas que se achavam sob controle do narcotráfico. Os resultados dessas intervenções aliados aos temores de que tal envolvimento não constituiria solução adequada para o problema maior, qual seja, a intensificação do tráfico em novas modalidades, ocasionaram desgastes para as Forças Armadas. Isso se deveu ao fato de que a ação militar desencadeada pelas Forças Armadas se restringia a combater os sintomas do narcotráfico, ou seja, a violência urbana e não suas causas.

As Operações Rio I e II deixaram lições. Atualmente, nas formulações de políticas de combate ao crime organizado e diminuição da violênciaurbana se exige que sejam atacadas as causas do narcotráfico através da presença do Estado na forma de prestação de serviços em áreas da educação, saúde, habitação, saneamento básico e segurança coletiva. A política de combate às drogas é concebida como sendo deâmbito nacional, lutando aqui contra a rede internacional que tem o Brasil como ponto de passagem. Paralelamente a isso, combate às redes locais, voltadas para o comércio de varejo da droga.

Observa-se que o governo de Fernando Henrique Cardoso tende a demonstrar disposição de atuar com vigor na repressão às drogas. Prova disso é a destinação de fundos para o reaparelhamento da Polícia Federal, a reestruturação e o revigoramento do Conselho Federal de Entorpecentes e a intensificação da cooperação internacional em âmbito bilateral, regional e multilateral. Igualmente 
relevante é o maior engajamento das Forças Armadas, não apenas no que concerne ao apoio logístico em matéria de inteligência, mas igualmente em operações de repressão direta nas circunstâncias em que seu emprego venha a ser requerido. É cedo para dizer se tal engajamento constitui protelação para o envolvimento dos militares na guerra das drogas ou se é mais uma vitória dos Estados Unidos que, pouco a pouco, conseguem colocar os exércitos latinoamericanos nesta luta que se antevê fadada à derrota, porque sabe-se que não são as balas que combatem as drogas.

Em um plano secundário na formulação da política de combate ao narcotráfico fica o Ministério das Relações Exteriores. Este atua junto aos principais organismos internacionais, notadamente as Nações Unidas e a Organização dos Estados Americanos. O MRE é responsável, em conjunto com o Ministério da Justiça, pela negociação de tratados multilaterais e bilaterais em matéria de cooperação frente ao narcotráfico. Entretanto, número considerável desses tratados são esquecidos, permanecendo como letra morta. ${ }^{6}$

Quanto aos resultados e efeitos do combate ao narcotráfico, pode-se avaliá-los como modestos. Nos últimos anos, efetivamente, lograram-se níveis crescentes de apreensão de drogas, sobretudo aquelas com destino ao exterior, que chegaram a quase 13 toneladas em 1994 e 15 toneladas em 1995 como adiante se verá. Isto significa em grande medida que os esforços da repressão ainda estão canalizados para impedir a saída, enquanto descuidam-se da entrada no Brasil. O tráfico de drogas aumenta rapidamente, pois o volume da droga confiscada corresponde somente a $10 \%$ do volume traficado.

A disseminação do uso de drogas naturais e sintéticas, particularmente a cocaína e seus derivados, e da cola de sapateiro entre as camadas sociais mais pobres, comprova a ausência de políticas efetivas de prevenção, controle e repressão ao uso e ao abuso de drogas. ${ }^{7}$ Estima-se em cerca de oito milhões o número de usuários de drogas pesadas no Brasil. Do mesmo modo, a atuação dos órgãos de repressão ao tráfico não tem conseguido coibir internamente a expansão das drogas e nem reverter a crescente importância do País nas distintas fases da economia do narcotráfico.

A ausência de controle do espaço aéreo no Norte e no Nordeste do País, a urbanização desordenada, a desestruturação da família, o esgarçamento do tecido social, a escassa presença das forças militares nas áreas de fronteira, as características geográficas refletidas na grande extensão do território, somadas às clivagens sócio-culturais, cultura política clientelista e corrupta, comprovam a complexidade do universo das drogas. Indicam o quanto é difícil a implementação de política eficaz de combate às drogas no País. 


\section{Evolução e modalidade do narcotráfico}

Os dados sobre a apreensão de drogas pela Polícia Federal em todo o país no período compreendido entre 1993 e 1996 atestam as dificuldades decorrentes da insuficiência de recursos financeiros, materiais e humanos no combate ao tráfico de entorpecentes. Revelam a capacidade que os grupos responsáveis pelo tráfico têm de modificar suas estratégias e rotas, tendo em vista a atuação policial. Nesse sentido destaca-se que, ao lado da intensificação do tráfico de entorpecentes observada a partir de 1995, registra-se diminuição nas apreensões tanto de cocaína como de maconha no mesmo período, após uma fase de intensificação da repressão entre 1993 e início de 1994, conforme se vê na Tabela 1.

\section{TABELA 1}

Brasil: Total de Drogas Apreendidas 1993-1996(Kg.)

\begin{tabular}{lllll}
\hline & $\mathbf{1 9 9 3}$ & $\mathbf{1 9 9 4}$ & $\mathbf{1 9 9 5}$ & $\mathbf{1 9 9 6}$ \\
\hline cocaína & 7272 & 11837 & 5342 & 1019 \\
pasta básica & 230 & 171.5 & 590 & 12.8 \\
maconha/pés & 8599 & 18836 & 11733 & 7903 \\
“crack” & 0.050 & 33 & 10 & 8.3 \\
heroína & - & 12.7 & 0.056 & - \\
\hline
\end{tabular}

Fonte: Divisão de Repressão a Entorpecentes, Departamento da Polícia Federal

Essa diminuição, em vez derepresentarredução notráfico de entorpecentes, significa que os esforços para a sua repressão estão longe do necessário para fazer frente ao problema. Ainda mais estranho é o fato dessa diminuição coincidir com o período em que o Governo Federal adotou política dita rigorosa com relação ao tráfico e ao consumo de drogas ilícitas. Seu objetivo é precisamente conferir efetiva capacidade de atuação às forças policiais no combate ao narcotráfico, contando, conforme mencionado, com o envolvimento das Forças Armadas, segundodeterminação presidencial. ${ }^{8}$ Por outro lado, é maior a atenção das Forças Armadas e são expressivos os recursos destinados à Polícia Federal bem como a série de medidas legais adotadas com o propósito de aumentar o controle sobre o tráfico de drogas e sobre a lavagem de dinheiro.

Teoricamente, a recente política do Governo Federal começa a voltarse para outros aspectos que compõem o problema das drogas no País. Sua relação direta ou indireta com o narcotráfico internacional requer atenção 
específica, como por exemplo no que diz respeito ao controle sobre solventes, tranqüilizantes e anfetaminas, as drogas mais usadas, sobretudo no meio estudantil e pelas crianças de rua, segundo dados da Escola Paulista de Medicina, excluído o fumo e o álcool. ${ }^{9}$ Hoje em dia, os solventes e os tranqüilizantes superam a maconha, terceira droga mais usada. O aumento da expansão de viciados em anfetaminas é mais rápido inclusive que o crescimento de dependentes da cocaína. Isso apesar de continuar em ascendência o consumo de cocaína nos Estados de São Paulo, Rio de Janeiro, Minas Gerais, Paraná, Santa Catarina, Rio Grande do Sul e Distrito Federal, partes do país onde o poder aquisitivo da população é maior. Nos Estados do Rio de Janeiro e de São Paulo registra-se o maior número de assaltos, criminalidade e desvio de carga. Tal violência envolve as camadas sociais de baixa, média e alta renda, tanto no tráfico como no consumo das drogas.

Apesar da cocaína não ser a única droga usada, a prioridade, em relação à prevenção e combate ao uso de drogas ilícitas, costuma recair sobre as drogas pesadas. O combate ao tráfico de drogas ilícitas esquece a cola de sapateiro e vários medicamentos comprados em farmácias. Como mencionado, os esforços de repressão concentram-se em pontos de saída e de trânsito da droga, o que se reflete nas estatísticas de apreensões, sobretudo nas regiões Centro-Oeste, Sudeste e Sul.

Nesse sentido, destaca-se o crescimento entre 1993e 1996 das apreensões de cocaína, pasta básica e maconha na região Centro-Oeste, o que indica a transformação dessa região em importante espaço para o tráfico de entorpecentes interno e externo. Tal fato resulta possivelmente da existência de malha de transporte interligada às outras regiões e da posição geográfica central. Grande número de pequenas pistas de pouso e a facilidade de acesso aos grandes centros de distribuição, consumo e exportação de drogas contribuem para umbicar definitivamente o Centro-Oeste na rota das drogas.

\section{TABELA 2}

Apreensão de Drogas: Região Centro-Oeste(Kg.)

\begin{tabular}{lllll}
\hline & $\mathbf{1 9 9 3}$ & $\mathbf{1 9 9 4}$ & $\mathbf{1 9 9 5}$ & $\mathbf{1 9 9 6}$ \\
\hline cocaína & 1625 & 1910 & 2311 & 342.5 \\
maconha & 2988 & 2738 & 3534 & 1200 \\
pasta básica & 116.8 & 147.9 & 376.5 & 10.7 \\
maconha/pés & 72 & 24 & 400 & - \\
\hline
\end{tabular}

Fonte: Divisão de Repressão a Entorpecentes, Departamento da Polícia Federal 
Observa-se que as apreensões na região Norte diminuíram significativamente desde 1994, sugerindo, por um lado, o elevado nível de dificuldade operacional na região e, por outro, o empenho por parte dos narcotraficantes em buscar novas rotas de acesso aos principais mercados de destino, evitando as grandes distâncias.

\section{TABELA 3}

Apreensão de Drogas: Região Norte-1993/1996(Kg.)

\begin{tabular}{lllll}
\hline & $\mathbf{1 9 9 3}$ & $\mathbf{1 9 9 4}$ & $\mathbf{1 9 9 5}$ & $\mathbf{1 9 9 6}$ \\
\hline cocaína & 1740 & 8425 & 403 & 131.3 \\
maconha & - & - & - & - \\
pasta básica & 95 & 23 & 24 & 12.8 \\
maconha/pés & 18 & 8 & 3 & - \\
\hline
\end{tabular}

Fonte: Divisão de Repressão a Entorpecentes, Departamento da Polícia Federal

Não existem registros sobre a expansão das plantações de ipadu na Amazônia brasileira nesta década. Segundo informações recolhidas junta à Polícia Federal, entre 1988 e 1990, adotaram-se medidas para sua erradicação. Para tal, esforços foram empenhados junto às comunidades indígenas; algumas delas passaram a colaborar com as autoridades policiais no monitoramento das culturas da droga e de seu uso.

No decorrer do texto, o leitor deparar-se-á com diferentes preços de drogas. Isso porque o preço cai quando diminui a repressão. Com estoques desovados, o mercado inunda-se da droga. A lei da oferta e da procura dita os preços. Os distintos valores apresentados nesse trabalho refletem essa lei.

Sabe-se que a distância entre o local de produção e de processamento tem reflexos sobre o preço da droga para o consumidor. Apesar de dificultar a ação repressiva e de facilitar o tráfico, as grandes distâncias, particularmente na região Norte, de alguma forma acabam repercutindo sobre o preço de venda. Segundo levantamentos da Polícia Federal concluídos em 1996, o preço da cocaína, por exemplo, variava entre Estados e regiões, como reflexo do grau de vigilância policial. A demanda e a oferta são eventualmente afetadas quando ocorrem grandes apreensões. O quilo da cocaína em Ponta Porã, ponto tradicional de entrada da droga em Mato Grosso do Sul, oscila entre US\$2.500 e US\$3.000. Em outras cidades do Mato Grosso do Sul e em São Paulo tem permanecido entre US\$ 3.000 e US\$ 4.000. No Rio de Janeiro e no Rio Grande do Sul estava na faixa de US\$ 4.000 a US\$ 5.000 e em Santa Catarina de US\$ 6.000. 
O mesmo fenômeno ocorre com relação à maconha. Segundo o citado levantamento, seu preço é de $\mathrm{R} \$ 40,00$ a $\mathrm{R} \$ 50,00$ o quilo no sertão de Pernambuco.Em Ponta Porã (MS), o quilo oscila entre R\$50,00 e 100,00. O quilo da maconha chega a custar R\$ 250,00 em Santa Catarina e R\$ 300,00 no Rio Grande do Sul. Em São Paulo pode alcançar R \$ 800,00. No Rio de Janeiro, entre R \$ 1.000 e R \$1.200. A cotação elevada da maconha no Rio de Janeiro e em São Paulo deve-se aos altos níveis de consumo da droga, conforme atestam as grandes apreensões nesses Estados registradas nas tabelas 4 e 5.

TABELA 4

Apreensão de Drogas: Região Sudeste(Kg.)

\begin{tabular}{lllll}
\hline & $\mathbf{1 9 9 3}$ & $\mathbf{1 9 9 4}$ & $\mathbf{1 9 9 5}$ & $\mathbf{1 9 9 6}$ \\
\hline cocaína & 1333 & 1086 & 1847 & 427 \\
maconha & 1405 & 3346 & 1120 & 2317 \\
pasta básica & 95.9 & - & 146 & 1 \\
maconha/pés & 21 & - & - & 410 \\
\hline
\end{tabular}

Fonte: Divisão de Repressão a Entorpecentes, Departamento da Polícia Federal

TABELA 5

Apreensão de Drogas: Região Sul(Kg.)

\begin{tabular}{lllll}
\hline & $\mathbf{1 9 9 3}$ & $\mathbf{1 9 9 4}$ & $\mathbf{1 9 9 5}$ & $\mathbf{1 9 9 6}$ \\
\hline cocaína & 2315 & 320 & 495 & 96 \\
maconha & 1459 & 5992 & 2072 & 3823 \\
pasta básica & 1.8 & - & 40 & - \\
maconha/pés & 48 & 70 & 4 & - \\
\hline
\end{tabular}

Fonte: Divisão de Repressão a Entorpecentes, Departamento da Polícia Federal

No que tange à região Nordeste, é mister considerar o impacto do crescente fluxo de turistas estrangeiros nos últimos anos sobre as condições para a intensificação do tráfico de entorpecentes. Cidades como Fortaleza, Salvador, Natal, Recife e Maceió atraem quantidades crescentes de turistas nacionais e estrangeiros, dentre estes especialmente os europeus. Aumentou igualmente o número de vôos nacionais e internacionais com destino a essas capitais. Essa 
tendência, no entanto, não se reflete claramente nos dados da apreensão de drogas, que são significativamente inferiores em relação às demais regiões, com exceção da maconha.

\section{TABELA 6}

Apreensão de Drogas: Região Nordeste (Kg)

\begin{tabular}{lllll}
\hline & $\mathbf{1 9 9 3}$ & $\mathbf{1 9 9 4}$ & $\mathbf{1 9 9 5}$ & $\mathbf{1 9 9 6}$ \\
\hline cocaína & 258 & 94 & 284 & 21 \\
maconha & 2745 & 6759 & 5005 & 563 \\
pasta básica & 450 & - & 4 & - \\
maconha/pés & 1854 & 2215 & 2532 & 250 \\
\hline
\end{tabular}

Fonte: Divisão de Repressão a Entorpecentes, Departamento da Polícia Federal

Os fenômenos da prostituição, sobretudo infantil, o recrudescimento da criminalidade e das atividades ligadas à economia informal são claros. $\mathrm{O}$ aumento do uso das drogas na região Nordeste associado ao incremento do fluxo turístico não quer dizer necessariamente que a região esteja ganhando concomitante importância no que se refere ao tráfico internacional. Por não haver informações precisas disponíveis, qualquer interpretação nesse sentido será precipitada.

Os últimos dados sobre as apreensões de drogas sugerem a presença de heroína principalmente em São Paulo, porém em escala reduzida, não sendo o comércio dessa droga até meados dos anos 90 objeto de específica análise por parte da Polícia Federal. O que chama atenção é o crescimento das apreensões de pasta básica entre 1993 e 1995, sugerindo tendência de aumento do seu tráfico, ainda que em pequenas quantidades.

Outro indicador da evolução do narcotráfico, além das apreensões de drogas, é o número de inquéritos instaurados por tráfico. Cabe destacar que, apesar de o uso de drogas continuar sendo proibido por lei, há clara tendência no sentido de enfatizar mais a criminalização do tráfico e menos do uso. Por essa razão, tomou-se como indicador o percentual de inquéritos por tráfico de drogas. A quantidade de inquéritos policiais abertos anualmente diminui. Em 1993 instalaram-se 1.899, contra1.602 em 1995. Atémaio de 1996, havia470 inquéritos.

Do mesmo modo, o número de pessoas indiciadas por tráfico de drogas caiu de 2.128 em 1993 para 1.833 em 1995 e 536 até maio de 1996. Para se ter idéia das diversidades da origem e da nacionalidade das pessoas indiciadas, tomouse como parâmetro o período de janeiro a maio de 1996, quando o Departamento 
de Polícia Federal indiciou por tráfico de drogas, além de nigerianos, quatro cidadãos da África do Sul, um da Alemanha, um deAngola, dois da Argentina, um da Austrália, sete da Bolívia, um do Canadá, um do Chile, um da Colômbia, um da Espanha, três da Grécia, três da Holanda, dois da Itália, um da Jordânia, um do Quênia, um do Líbano, dois do México, dois de Moçambique, um da Namíbia, sete do Paraguai, quatro de Portugal, um da Suíça, quatro da Zâmbia e trezentos e quarenta e seis brasileiros. Cerca de um quinto do total das pessoas indiciadas é do sexo feminino, da faixa etária entre 25 e 29 anos. ${ }^{10}$

Esses dados levam a conclusão de que os esforços para desenvolver uma política consistente no combate ao tráfico de drogas não alcançaram os resultados almejados. Como o mencionado, a diminuição nos números não traduz necessariamente redução do tráfico, mas, sim, a limitação dos instrumentos de Estado na prevenção e na repressão ao tráfico.

\section{Fatos, tendências e perspectivas no mundo das drogas}

O estudo da sociologia do narcotráfico contempla o fenômeno e suas etapas em uma análise essencialmente global. Isso não impede procurar características, perspectivas e fatores circunstanciais nas diferentes camadas sociais onde o narcotráfico se move. As estruturas do narcotráfico e sua operação respondem tanto a estímulos de mercado, em sua dimensão transnacional e global, como a fatores e circunstâncias de ordem doméstica e mesmo local que definem o modo de inserção de um país no contexto do narcotráfico internacional e as condições específicas de seu funcionamento.

A contingência de ter que responder e reagir simultaneamente a fatores que operam em distintosníveisimpinge ao narcotráfico característica de flexibilidade e desafia sua capacidade de promover articulações e rearticulações necessárias para atender aos estímulos de mercado e manter sua operacionalidade nas diferentes etapas em que se desdobra, como na da produção, processamento, trânsito, comercialização e lavagem de dinheiro. Tudo isso em face dos esforços de repressão e controle empreendidos pelos governos. Por esta razão, as estruturas do narcotráfico não são homogêneas e nem se desenvolvem de modo uniforme entre os países, o que indubitavelmente acarreta grande dificuldade para a concepção e a implementação de estratégias de repressão em nível nacional e transnacional.

A extensão do território, das fronteiras e vasta costa marítima, a vizinhança com os principais centros produtores, a existência de infra-estrutura de transportes e de comunicações bem desenvolvida colocam o Brasil em posição privilegiada 
nos negócios das drogas. Afora isso, o País conta com um sistema financeiro que cresceu sem mecanismos de controle eficazes.

As características estruturais do narcotráfico no Brasil se desenvolveram inicialmente a partir de sua condição primordial de país de trânsito, que o diferenciou dos países produtores ou eminentemente consumidores. Essa característica voltada para uma atividade meio, o trânsito, faz com que grupos atuantes neste segmento do narcotráfico, como no caso brasileiro, estejam operacionalmente vinculados às estruturas e organizações nas duas pontas do processo. Ou seja, vínculos com países produtores e consumidores. Por conseqüência, ligações com os grandes cartéis internacionais, como aquelas existentes nos principais centros de consumo e produção às demais estruturas de contravenção associadas ao narcotráfico. De todas elas, os narcotraficantes brasileiros recolhem e adaptam experiências em processo de contínuo aprendizado, permitindo-lhes definir formas eficazes de atuação. Issogera capacidade adaptativa às mudanças que ora o mercado, ora as ações repressivas introduzem.

Ao mesmo tempo, estenível de integração operativa com outras estruturas do narcotráfico internacional decorrente de seu papel intermediário faz com que inexista sentido proeminente de competição ou de rivalidade com os grandes cartéis internacionais. Isso impõe aos narcotraficantes brasileiros a necessidade de desenvolver vínculos cooperativos tanto com os cartéis quanto com as organizações criminosas associadas ao narcotráfico.

Assim, por exemplo, os narcotraficantes brasileiros aprenderam com as máfias italianas e japonesas e com seus vizinhos narcotraficantes colombianos suas táticas, o que permitiu que o traficante daqui ampliasse seu campo de ação. Esse campo, nos anos sessenta, estava limitado a São Paulo, que continua sendo o epicentro das drogas, sem esquecer, é claro, o protagônico papel da cidade do Rio de Janeiro. Agora, na década de noventa, toda a costa atlântica e toda a região amazônica estão nas mãos de narcotraficantes sobretudo brasileiros, o mesmo ocorrendo em extensas faixas da fronteira com a Argentina, o Paraguai, a Bolívia, o Peru, a Colômbia e a Venezuela. A ação de outras máfias como a libanesa, a japonesa, a russa, é tolerada porque, até o presente, não entraram no mercado interno de distribuição. Sendo assim, não oferecem concorrência aos traficantes locais.

Não existem estudos nem uma história da política de cooperação entre o narcotráfico de países europeus com o narcotráfico na América Latina. No entanto, a "política de cooperação” do mundo da contravenção tanto é real que rende frutos. Os esquemas são perfeitamente visíveis: ajudaram a tornar madura, rápida e operante a contravenção no Brasil.É necessário ver que os narcotraficantes 
brasileiros passaram de aprendizes a mestres. Tem havido grande mobilidade social no universo do narcotráfico. Nesse mundo, pessoas de diferentes classes sociais se encontram e se misturam. Os códigos de conduta do banditismo passam por cima da questão da origem social e do berço. Eles contemplam, aos que aplicam com maior rigor a violência, o monopólio do prestígio na etapa da distribuição para o consumo.

Em termos comparativos, o narcotraficante brasileiro é particularmente cooperativo porque, como se verá em seguida, em seu País nunca se formaram cartéis ou máfias ao estilo dos colombianos, sicilianos, peruanos, franceses, japoneses, coreanos, chineses e libaneses. As autoridades policiais e a imprensa brasileira usam freqüentemente expressões tais como "cartel de Rondônia”, “cartel do Rio”, etc., mas efetivamente a contravenção no Brasil nunca formou cartéis dignos desse nome.

A venda, o consumo e a produção das drogas no Brasil parecem ter nascido multipolarizados. Se levarmos em conta as dimensões territoriais do país e sua geopolítica, as inteligências que controlam o narcotráfico nacional, de forma intencional ou não, estiveram corretas ao apostar no caráter múltiplo e fragmentado de suas bases e na pulverização das estratégias usadas na expansão do processo.

O narcotráfico prosperou no Brasil não apenas devido à adoção de estratégias adequadas e à agilidade e destreza dos contraventores em face de condições econômicas e sociais igualmente favoráveis, mas também devido à inexistência no país de uma consistente política antidrogas As limitações da cooperação internacional nesse campo, os equívocos oriundos de Washington, com gestos pouco ou nada sensíveis às realidades sociais da América Latina, em nada ajudam à luta contra as drogas.

Omundo da contravenção éimprevisível eincontrolável. Suas ramificações "invisíveis" alcançam segmentos em praticamente todos os níveis sociais, inclusive dentro das forças criadas para seu controle e erradicação. O narcotraficante brasileiro tem respostas. Suas decisões imediatas são apoiadas por complexa infra-estrutura operativa descrita a seguir.

Conforme já se registrou, a estrutura do narcotráfico no Brasil possui elementos característicos que, de alguma forma, a diferencia dos outros na América Latina. Ainda que, em quase todos os países diretamente afetados pelo tráfico de drogas, as vinculações entre narcotráfico e atividades ilegais como o terrorismo, a corrupção, a lavagem de dinheiro, o tráfico de armas, o roubo de carro e o contrabando de mercadorias sejam realidade, faz-se necessário distinguir as estruturas de organização dos eminentemente produtores de drogas, como Peru, 
Bolívia e Colômbia, das de nações que possuem outro perfil de envolvimento com o narcotráfico, como é o caso Brasil.

No caso colombiano, a título de exemplo, tal estrutura está conformada principalmente pelos cartéis controladores da produção e da comercialização em rede que alcança agentes internos e externos e se estende aos mercados de consumo finais. Os cartéis possuem, portanto, uma estrutura que, em princípio, deve sustentar-se em capacidades operativas próprias. As vinculações com outras estruturas delitivas representam modo de maximizar suas próprias capacidades e de garantir condições de proteção e operacionalidade ao longo de todo o processo de produção, processamento e de comercialização. Trata-se de padrão organizacional estruturado combase em grandes unidades de comandohierárquico, o que torna possível conhecer melhor quem são os grandes nomes do narcotráfico e identificar suas respectivas organizações.

No Brasil, o narcotráfico não possui estrutura semelhante à dos cartéis colombianos. Como se disse, mesmo encontrando com freqüência referências a alguns cartéis, é necessário tomar em conta que o emprego da expressão “cartéis” para designar as estruturas de operação do narcotráfico no Brasil pode conduzir a interpretações equivocadas. É difícil comparar a estrutura aqui existente com a dos países produtores, uma vez que no Brasil a estratégia do narcotráfico é quase guerrilheira, vale dizer, fragmentada e pulverizada em pequenos núcleos ágeis e, sobretudo, operativos.

A estrutura do narcotráfico no Brasil nasceu vinculada ao contrabando, à evasão de riquezas nacionais e à corrupção governamental. Estabelece ligações com a contravenção e com o crime organizado, sobretudo junto às máfias italianas, japonesas e libanesas eatéhoje cresce vitalizada pelo contrabando de ouro, pedras preciosas, madeiras nobres, pelo mercado de carros roubados, bens de consumo e de armas. É, portanto, estrutura de comando e operação extremamente sólida e difusa e, por isso, complexa e menos hierarquizada que a dos cartéis tradicionais.

Quanto à distribuição das drogas no mercado interno e para exportação, essa estrutura é dependente dos vínculos com os grandes cartéis produtores, sobretudo no caso da cocaína e, agora, também da heroína, cujo tráfico e consumo embora ainda pequenos no Brasil, tendem a aumentar. A capacidade de comando do tráfico, por ser regionalizada, é de menor alcance em termos geográficos. O que se perde em termos de extensão ganha-se com o eficiente gerenciamento do processo de distribuição. Em termos de definições estratégicas, parece que estas provêm dos grandes cartéis, umbicados tanto na Colômbia quanto nos Estados Unidos e na Europa, aos quais se vinculam os grupos de traficantes do Brasil. 
É possível apontar dois grandes segmentos do narcotráfico no Brasil: o primeiro dedica-se ao tráfico internacional, movimentandograndes quantidades de droga e de dinheiro, mas com número de pessoas relativamente reduzido. De acordo com estimativas do Departamento de Polícia Federal, cerca dequatrocentas pessoas atuam nesse segmento do narcotráfico; possuem alto nível de renda, constituem empresas, sobretudo em atividades de exportação nos grandes centros urbanos, com destaque para os Estados de São Paulo, Rio de Janeiro e Amazonas, onde se localizam importantes portos e aeroportos internacionais. Estima-se que esse segmento manipula cerca de 120 toneladas de cocaína pura por ano. Nele atuam as máfias da Europa, Oriente Médioe Ásia, cujos representantes concentramseparticularmenteem São Paulo. ${ }^{11}$ Também estão em São Paulo os principais elos com os grandes grupos de contrabando localizados nas cidades de fronteira com o Paraguai, como Foz do Iguaçú, Ciudad del Este e Ponta Porã; bem como Corumbá, na fronteira com a Bolívia. ${ }^{12}$

Basicamente três grupos de narcotraficantes no Brasil possuem sólidas conexões internacionais. O primeiro é comandado por Antonio Mota Graças, conhecido por "Curica”. Este atua a partir da Colômbia, estabelecendo vínculos com grupos no Brasil, sobretudo nos Estados da Amazônia Legal. O segundo é comandado por Fahad Amil Jorge, de origem árabe, que age no Mato Grosso do Sul. Talvez, graças a seu grupo, a droga chega ao Líbano, a outros países do Oriente Médio e Europa. O terceiro grupo éliderado por Augusto Morbachi Neto que transita pelo Centro-Oeste e região amazônica. Os demais estabelecem vinculações pontuais para a aquisição de droga, sobretudo na Bolívia. ${ }^{13}$

Com relação à atuação das máfias internacionais do narcotráfico no Brasil, de acordo com informações da INTERPOL e da Polícia Federal, estimase que cerca de cinqüenta integrantes estrangeiros de distintas facções da máfia italiana estejam no país. Metade destes em São Paulo e os demais no Rio de Janeiro, Bahia, Ceará e Pernambuco, onde trabalham nos esquemas do tráfico de cocaína e lavagem de dinheiro, utilizando como fachada restaurantes, hotéis, fazendas e até instituições de caridade. Pelo menos quatro facções estão presentes no Brasil: a Camorra Napolitana, a N'draghetta Calabresa, a Cosa Nostra e a Sacra Corona Unita, estas duas últimas sicilianas ${ }^{14}$.

No segmento do narcotráfico voltado para a exportação associam-se os dedicados ao contrabando. A abertura comercial facilitou a entrada de importações e estimulou grupos e indivíduos que exerciam o contrabando de bens e de commodities a mudar de produtos ou a agregar a eles o comércio de drogas ilícitas. ${ }^{15}$ Localizam-se sobretudo em cidades próximas à fronteira com Paraguai e Bolívia. Há evidências de conflitos entre esses grupos. A Polícia Federal 
conhece os nomes de contrabandistas-traficantes, mas tem dificuldade de atuar, visto ser fácil aos bandidos e proibido à polícia cruzar a fronteira nessas regiões. Em Ponta-Porã e Pedro Juan Caballero, a exemplo de outras cidades fronteiriças, o marco divisório está no centro das duas cidades.

No outro segmento estão os dedicados à distribuição e venda de drogas no mercado doméstico, particularmente nos grandes centros urbanos, em volume, os maiores mercados de consumo de drogas ilícitas. O tráfico interno mobiliza número significativamente maior de pessoas. Essa cadeia compõe-se de indivíduos que exercem funções distintas: os contatos com os atacadistas da droga, normalmente pertencentes aos grandes cartéis produtores, nos países vizinhos, são feitos através de um intermediário, “matuto”, que adquire a droga e contrata os que irão transportá-la para o exterior, as “mulas”, que entregam a cocaína aos pequenos traficantes. Estes, por sua vez, a distribuem em pequenas quantidades para venda, nas mãos dos “vapores”. Da mesma forma existe a figura do “avião”, integrada quase exclusivamente por adolescentes e crianças que levam os consumidores aos "vapores” ou que distribuem a droga, sem aumentar o preço da mesma. A droga há tempos é entregue à domicílio. Os que prestam esse serviço são chamados “esticas”. Popularizaram-se por todo o país os "fogueteiros" que, com recursos pirotécnicos, alertam os traficantes para a presença da polícia. ${ }^{16}$ Segundo estimativas da Polícia Federal, cerca de cento e cinqüenta mil pessoas atuam na cadeia do narcotráfico interno desempenhando distintas funções. A extensão do fenômeno faz crer que este contingente na realidade é significativamente maior.

Tal número, no entanto, não reflete estimativa segura, uma vez que o narcotráfico associa-se e, não raramente, confunde-se com outras atividades ilícitas, como o contrabando, o tráfico de armas, de veículos roubados e, mais importante, com infinidade de atividades relacionadas à economia informal. Apenas na cidade do Rio de Janeiro, segundo dados do Departamento de Narcóticos do Estado fluminense, cerca de cem mil pessoas estão direta ou indiretamente envolvidas nas atividades de distribuição e venda de drogas a pequenos consumidores. Alastram-se trabalhando em diferentes grupos de atuação, por sua vez vinculados a organizações criminosas como o Comando Vermelho, Comando Neutro e o Terceiro Comando que, embora disputem entre si o comando do narcotráfico, cooperam no sentido de enfrentar a repressão policial ou de garantir o abastecimento de drogas nas áreas em que atuam. Os números acima mencionados ilustram a confusão na selva das estatísticas referentes às drogas. Uma fonte aponta 150 mil em todo o Brasil, outra $100 \mathrm{mil}$ no Estado do Rio de Janeiro. Considerando São Paulo, Mato Grosso, Rondônia, 
Amazonas, Acre, Tocantins e Distrito Federal, com certeza o número real estará muito mais elevado.

Como resultado de estratégia aparentemente bem articulada, a inexistência de cartéis permite que as lideranças sejam substituídas “da noite para o dia”, sem interrupção e sem maiores problemas para a macroestrutura do narcotráfico nacional. Isso tornou-se possível pelo fato de o narcotráfico no Brasil não ser concêntrico, mas sim fragmentado.

As estruturas do narcotráfico estabelecem relação de simbiose com as de outras atividades ilegais, servindo como estímulo ou elemento de indução ao surgimento de organizações e grupos criminosos que procuram exercer controle sobre os negócios da droga em áreas específicas. Isto é particularmente claro no caso do antigo Estado da Guanabara, onde o narcotráfico constitui o epicentro de um complexo de organizações criminosas e de contravenção.

\section{Expansão e interiorização do comércio de drogas}

Por sua própria natureza ilegal e pela conseqüente necessidade de procurar escapar do monitoramento das forças de segurança, o narcotráfico, em suas diversas dimensões, tende a assumir características de constante inovação emutabilidade no tempo. Este aspecto é particularmente claro no que diz respeito às rotas utilizadas. As rotas do narcotráfico são constantemente transformadas e, em alguns casos, esquecidas por um espaço de tempo e depois rearticuladas e reutilizadas.

Neste universo de troca e mutação, parte da droga reexportada do Brasil para a América do Norte e a Europa vem da Colômbia, Peru e Bolívia, freqüentemente passando pelo Paraguai. São utilizados aeroportos clandestinos, pistas de aterrissagem em fazendas, caminhões transportadores de madeira e de gado com fundos falsos, além de automóveis particulares. A pasta básica que entra no Brasil através do Paraguai é produzida e processada em localidades de cultivo e colheita da coca; após o processamento das folhas seu peso se reduz, facilitando o transporte por via aérea, fluvial ou terrestre.

O maior problema para os produtores de coca em 1995 e 1996 esteve na dificuldade de obtenção de ácido sulfúrico e querosene. Nos anos oitenta, esses produtos entravam e saíam do Brasil por Tabatinga, no Estado do Amazonas, fronteira com a cidade colombiana de Leticia. Por haver se tornado rota costumeiramente empregada, ficou policiada. A pasta básica que entra ou que é processada no Acre, Rondônia, Mato Grosso, Mato Grosso do Sul, Tocantins e 
Goiás, segue para as cidades do interior de São Paulo e de Minas Gerais, antes de ser embarcada em portos marítimos dos Estados do Paraná, São Paulo e Espírito Santo. Esta rota recebeu o nome de “rota caipira”, por seu caráter interiorano. Ela tem sido usada também para o estoque da cocaína ${ }^{17}$.

Supõe-se que as ferrovias sejam utilizadas pelos narcotraficantes que misturam a cocaína em sacas de café ou de trigo. A rota caipira tem o apoio da máfia italiana e da União Corsa (máfia francesa). Pela rota caipira se transporta a heroína, uma pequena parte produzida na Colômbia e outra grande parte procedente da Ásia. Em tais casos, a droga chega a Ciudad del Este, Manaus e até mesmo a Ushuaia que, por serem zonas francas, fornecem infra-estrutura física, humana e bancária extremamente favoráveis ao contrabando e ao narcotráfico.

Até os anos oitenta, o Brasil era o único país na América do Sul a fabricar o éter e a acetona em escala industrial. Por este motivo, com a imposição de rigor na fiscalização de tais produtos e constante vigilância da Drug Enforcement Agency (DEA), exigindo maior controle na exportação, parte da cocaína consumida no Brasil passou a ser processada aqui. Em razão da vigilância policial praticada sobre os químicos controlados na fase da produção, tornou-se comum o desvio dos mesmos.

É difícil dizer o quanto Peru, Colômbia e Bolívia exportam em pasta básica e em cocaína e o quanto destes produtos o Brasil consome e reexporta. O certo é que as estratégias são tão diversificadas a ponto de se saber que até o ipadu foi e ainda é plantado em escala comercial na região da Cabeça de Cachorro, no Estado do Amazonas. É, pois, importante considerar que rotas dos anos oitenta, depois de vigiadas e esquecidas, podem ser reutilizadas em outros momentos. Neste sentido, a região da cidade de Presidente Prudente, no interior do Estado de São Paulo, pode estar novamente transformando-se em receptora da droga que chega do Paraguai por via aérea seguindo daí para o Rio de Janeiro e São Paulo, por via terrestre. O mesmo pode ocorrer na Rodovia Raposo Tavares (SP270) que liga São Paulo a Mato Grosso do Sul. A Rodovia Castelo Branco (SP 280), a rodovia que liga São Paulo a Três Lagoas em Mato Grosso do Sul (SP 300) e a rota que liga Assis a Ribeirão Preto (SP 333), e dali a Minas Gerais, são todas, certamente, importantes para o narcotráfico.

A existência de tais rotas e sua malha envolvendo o Estado de São Paulo atestam ser este Estado e sua capital importante centro do negócio das drogas no país. Mais talvez que outros centros como o Rio de Janeiro ou Rondônia.

No Brasil, a repressão ao narcotráfico concentra-se tradicionalmente nas grandes cidades. $\mathrm{O}$ foco de atenção dos órgãos de informação, de inteligência e 
de quase todo o aparato policial centralizou-se principalmente nas capitais e em particular, Rio de Janeiro, São Paulo, Recife, Belo Horizonte, Salvador, Manaus, Brasília, Fortaleza, Porto Velho, Belém, Curitiba e Goiânia. Na maior parte dessas cidades existem consulados, onde ficam normalmente os escritórios da DEA e as redes de comunicações.

Nas capitais dos Estados mencionados, há efetivamente consumo de drogas, máfias, gangues, distribuidores, lavadores de dinheiro e fabricantes de produtos químicos controlados. No entanto, é fundamental observar que a inteligência que controla e fomenta o narcotráfico, sua estrutura de produção e logística de distribuição para o país e para o exterior não estão necessariamente nas capitais acima mencionadas, podendo estar no exterior.

A logística da estrutura produtiva do narcotráfico no Brasil desde a crise dos grandes cartéis colombianos passou por radical processo de descentralização. As estruturas de comando se multiplicaram, distribuindo-se por vários lugares no exterior e interior do país, em várias ramificações e em mãos de máfias de diferentes procedências geográficas.

O êxito da estratégia da micro e da macrodistribuição simultânea de drogas e produtos químicos criou inovações na produção. O cultivo da papoula substituiu certas áreas onde antes se plantava a coca na Colômbia. Por outro lado, as plantações de coca extrapolaram as fronteiras dos produtores tradicionais, ou seja, Peru e Bolívia, alcançando o Equador e a Venezuela, entre outros. Nesse processo de interiorização, as pequenas e médias cidades têm importância, não só as da Amazônia, mas as de Estados considerados fortes no País, ou seja, São Paulo e Minas Gerais. Em São Paulo, podemos mencionar Campinas, Santos, Ribeirão Preto,Aparecida do Norte e Araçatuba entre outras. Em Minas Gerais, Governador Valadares, Uberaba, Uberlândia, Diamantina, Paracatu, Varginha, Pouso Alegre, Theofilo Otoni e Juiz de Fora.

A penetração do narcotráfico nos centros urbanos de médio e pequeno porte em quase todos os Estados da Federação prova que as drogas não estão concentradas, como nos anos 70 e 80, nas metrópoles ou exclusivamente em cidades que fazem fronteira com a Colômbia, Peru, Bolívia e Paraguai. Um argumento forte a favor desse ponto de vista é o preço da cocaína. Nas cidades do interior, na maior parte dos casos, o preço é substantivamente inferior e a droga é de melhor qualidade. Dizem que o grau de pureza da cocaína distribuída no interior é maior do que aquela consumida no Rio de Janeiro e em São Paulo. Tanto isso é verdade que hoje levas de dependentes residentes nos grandes centros abastecem-se nas cidades do interior. 
A expansão do tráfico, da produção e do consumo de drogas, ou seja, o êxito da interiorização do narcotráfico no Brasil pode em parte ser debitada ao conjunto de erros da política antidrogas desenvolvida pelo Estado brasileiro. Durante duas décadas, as autoridades curvaram-se demasiadamente frente às pressões e aos ditames da DEA. Assim, os esforços nacionais contra as drogas se centraram quase que somente nos grandes portos marítimos e aeroportos, evitando a saída das drogas para o exterior, ou seja, para os Estados Unidos da América e a Europa Ocidental. Contudo, as autoridades esqueceram-se que uma política inteligente e efetiva deveria se preocupar com a entrada pelo "fundo" e, em conseqüência, com a saída pela "frente”.

Essa política afeta a toda a sociedade. Diante da abundância de drogas, os preços caem e elas ficam acessíveis. Milhares de cidadãos se viciam, ocasionando prejuízos sociais incalculáveis. Enquanto a polícia e os cães rastreadores vasculham aeroportos como Cumbica ou Galeão, as cidades fronteiriças e o interior brasileiro permanecem no abandono. Sem controle se transformaram, graças à inércia do Estado, em paraísos e bases para o narcotráfico, atraindo para si consumidores e vendedores de drogas.

A tática atual do narcotráfico no Brasil e na América Latina parece ser a descentralização, muitos e pequenos negócios. Arepressão dos Estados Unidos e a lição colombiana estão levando os narcotraficantes a espalharem-se pelo Brasil de norte a sul. Isso faz com que outros países como Chile, Argentina, Uruguai e Venezuela compartilhem com o Brasil as rotas de transporte para a Europa. O pequeno número de apreensões no Brasil com destino aos EUA indica que, no presente, a droga não está saindo diretamente daquele país. O mesmo pode acontecer com a cocaína para a Europa, que pode passar pelo Brasil, mas não necessariamente sair diretamente desse país para a Europa.

\section{Novas e velhas rotas}

Dentre as rotas fluviais e marítimas empregadas pelos narcotraficantes no Brasil, mais de uma centena possui conexões com a Bacia Amazônica, indo tanto em direção ao Atlântico quanto aos países andinos. Outra rota fluvial importante serve a região de Corumbá, Mato Grosso do Sul. Quase todo o Paraguai possui rotas fluviais utilizadas pelo narcotráfico. Nas margens do lago da hidrelétrica de Itaipu, a contravenção tem bases logísticas de apoio ao crime organizado. Outras rotas empregadas são as que se originam nos portos brasileiros, por onde saem as grandes exportações deminérios, e também de grãos, procedentes do Centro-Oeste, Sudeste e Sul do País. 
No entanto, a vigilância sobre os portos está levando os narcotraficantes a novas estratégias: parte da droga não é embarcada nos portos marítimos. Relembrando o que se disse anteriormente, pequenas embarcações entregam a droga em alto mar para grandes navios. As capitais dos Estados do Nordeste, com exceção de Teresina, estão localizadas na costa. Elas atraem bom número de turistas todo o ano. Dos seus portos a droga sai em pequenos barcos e é levada aos grandes navios distantes da costa. Alguns sequer atracam no Brasil. Fazem linha direta da África, Ásia e Oriente Médio para as Antilhas e América do Norte e vice-versa. O produto às vezes é desembarcado diretamente nos portos mediterrâneos. Iates de luxo ou barcos pequenos podem receber a droga em alto mar, desovando a mercadoria praticamente em qualquer lugar. Grandes portos como Hamburgo e Roterdã, por causa da fiscalização, sofrem a concorrência de pequenos, médios e grandes portos no Mediterrâneo, onde o suborno e a fiscalização facilitam o desembarque e a entrega de drogas da mesma forma que embarcam produtos químicos para o refino das mesmas na América Latina.

Algumas rotas aéreas igualmente se apresentam como importantes ao narcotráfico: aAeroflot faz escalas na Ilha do Sal, Chipre.Éumalinha privile-giada que alcança Bulgária, Polônia e a região balcânica da ex-Iugoslávia.

No segundo semestre de 1995, a Polícia Federal aprendeu 576 kg de cocaína escondidos em sacas de café em Mato Grosso destinadas à Turquia. Este fato comprova a tese, mencionada anteriormente, de que pequena parte da massa de turistas alemães, franceses, italianos e ingleses que vão em busca do turismo barato naquele lindíssimo país islâmico, com certeza viaja a serviço do narcotráfico. Isso comprova a hipótese de que as rotas se alternam, não se podendo dizer que grandes portos utilizados no passado não venham a ser reutilizados no futuro.

O tráfico de armas procedentes dos Estados Unidos utiliza tanto rotas marítimas quanto aéreas para chegar à América Latina. Existem suspeitas do envolvimento de policiais, burocratas e políticos no tráfico de armas, com certeza conectado com o contrabando de precursores químicos e com o narcotráfico. Difícil é a identificação dessas pessoas, já que há perigo de vida nesta situação. O porto de Paranaguá é outro ponto importante para o narcotráfico. Grupos árabes importam mercadorias para o Paraguai que voltam contrabandeadas para o Brasil. Os portos amazônicos no Brasil, na Colômbia, Peru e Bolívia são utilizados tanto para o contrabando de armas quanto para a entrada e saída de precursores químicos, da pasta base e da cocaína. 
No Brasil, aproximadamente 14.400 empresas estão legalmente autorizadas a produzir, transportar ou armazenar produtos químicos controlados. Para complicar esse quadro, hoje em dia, produtos químicos chegam até mesmo sem etiqueta do exterior. Ou seja, compra-se sem saber a origem, sem saber quem é o fabricante. Companhias multinacionais e nacionais fecham os olhos porque estão interessados em vender e em obter benefícios econômicos. Sabese que vários produtos usados na produção de cocaína e heroína são procedentes dos Estados Unidos da América. A Occidental Petroleum, por exemplo, teve toneladas de seus produtos químicos desviados para postos de refino tanto de cocaína quanto de heroína.

Na região amazônica, o dólar e outras moedas antes usadas, como o marco alemão e o franco suíço, perderam seu atrativo. Com a estabilidade da moeda, o pequeno traficante optou pelo real, que conseqüentemente é aceito por todos enão traz complicações. No entanto, trocar produtos químicos por armas ou cocaína é melhor do que trocar produtos químicos por dinheiro. Os vendedores de produtos químicos recebem como pagamento cocaína pura. A remuneração do transporte da droga que chega de Santa Cruz de la Sierra a Aquidauana no Mato Grosso do Sul ou a Costa Marques no Estado de Rondônia é acertada em quantidades dedroga.

Em Santa Cruz de la Sierra a cocaína pura, vendida em quantidades superiores a $30 \mathrm{~kg}$, valia, em outubro de 1996, 1.500 dólares por quilo. Em território brasileiro, no mesmo período, havia quem pagasse até 5.000 dólares por quilo. Nas ruas, um quilo de cocaína pura com as impurezas que lhe são incorporadas se transforma em quatro quilos para o consumidor comum. Esse fato faz com que o bom negócio, hoje, seja receber em cocaína pura o pagamento por serviços.

Não há como negar a interiorização das drogas e dos produtos químicos controlados. Os desvios de produtos de centenas de pequenas e grandes indústrias nacionais e estrangeiras espalhadas por todo o continente são comuns. Podem passar por Corumbá, Cáceres, Cacoal, Vilhena, Porto Velho, GuajaráMirim, seguindo para San Joaquím ou Santa Cruz de la Sierra, por via fluvial, férrea, rodoviária, aérea ou a pé. Qualquer estatística sobre esses dados é mero esforço de aproximação. É impossível expressar em quantidades o mundo dos ilícitos. Apenas pelo ar os serviços de informação da FAB constataram que entre Paraguai, Brasil e Argentina a média seja de aproximadamente 40 vôos irregulares por dia.

Nas reservas dos indígenas Yanomami, no Estado de Roraima, nas minas de ouro perto de Mucajaí e entre a capital, Boa Vista, e Surucucus, em outubro de 1996, foi detectada pela FAB uma média de 10 vôos irregulares ao dia. Este 
movimento em região com as mais baixas densidades demográficas do planeta leva a acreditar na formação de um novo triângulo do narcotráfico: Venezuela, Colômbia e Brasil. As atividades garimpeiras ajudam a despistar o contrabando de produtos químicos para a produção tanto da cocaína quanto da heroína na Colômbia. Em Caracaraí e nas proximidades das missões de Surucucus e Mucajaí, assim como na beira do rio Mucajaí, há presença intensa de narcotraficantes de diversas nacionalidades.

Congregações religiosas e a própria CNBB (Conferência Nacional dos Bispos do Brasil) demonstram profunda inquietação com a questão das drogas na Amazônia. Os militares, considerados quase inimigos no fim dos anos 80, devido ao "Projeto Calha Norte”, agora são novamente aliados na cruzada contra o narcotráfico. Assim as divergências entre a Igreja e as Forças Armadas vão sendo pouco a pouco esquecidas. ${ }^{18}$

Pari-Cachoeira, na divisa com a Colômbia, parece transformada em um discreto centro de distribuição. A população indígena da região, que não tem passaporte nem nacionalidade, passa tanto para o lado colombiano quanto para o brasileiro. Muitos caciques parecem estar a serviço das máfias colombianas. Na beira dos rios Traíra, fala-se de possíveis esconderijos de drogas e produtos químicos. Na bacia fluvial da região pode estar sendo montado o esquema de estocagem e distribuição das drogas para o Brasil e para o exterior, utilizando-se neste caso a rota venezuelana. Existem outras rotas como a que vem da Colômbia até Manaus e depois segue para Macapá. De Macapá segue para Oiapoque e para a Guiana Francesa, cujo caráter de província ultramarina a converte em caminho aberto para a França no começo dos anos 90.

No Brasil, como em qualquer outro país do mundo, não há controle de bagagem nas rotas internas. Companhias áreas regionais e nacionais, empresas de ônibus, trens, podem ser usadas por narcotraficantes para o transporte de pequenas e grandes quantidades de químicos e drogas. Em 1991 o Boeing 767 da companhia austríaca Lauda Air caiu matando 223 passageiros. Entre seus escombros encontraram-se $5 \mathrm{~kg}$ de heroína. Isso se repetiu no Brasil em 1996 com o avião Fokker 100 da TAM. Em seus escombros encontraram-se quase quatro quilos de cocaína. Esses fatos comprovam a tese da logística da distribuição alternada em micro e macroquantidades usadas pelos narcotraficantes. Como se constata, a rota das drogas não tem obstáculos geográficos. Ela está na selva, nos cerrados, em grandes ou pequenas cidades.

A integração do banditismo nas Américas é tão ousada a ponto de se roubar aviões. Aviões pequenos de modelos Cessna Skyline 206, 207 e 210 são freqüentemente roubados no Brasil. Esses aviões podem transportar de $200 \mathrm{a}$ 
500 kg de pasta base. Saem geralmente do Peru, da Colômbia e da Bolívia entrando no território brasileiro. No Brasil, faz-se o transporte para aviões mais sofisticados. Aeronaves Piper, Navajo, Sêneca Beecher Baron,Aerocommander, Citation e Lear Jet estão dentre as mais utilizadas no narcotráfico. Esses aviões costumam voar baixo e acompanhando leitos de rios. A destreza de seus pilotos e o conhecimento da selva dificultam a interceptação.

A ação da DEA no Peru e na Bolívia levou ao transbordo no Brasil. Esses aviões recebem carga e são abastecidos até nas pista da auto-estrada Porto Velho-Cuiabá, cujas retas permitem decolagem e pouso. No Brasil, a vigilância aérea de superfície é quase inexistente. AAmazônia toda conta com poucos radares. O grave é que esses radares cobrem somente os aeroportos das capitais. Faltam sensores de comunicação; sem estes as transmissões clandestinas continuam livres e a serviço do narcotráfico em praticamente todos os países amazônicos, ou seja, Bolívia, Brasil, Colômbia, Equador, Guiana, Peru, Suriname e Venezuela.

\section{A dimensão regional da cooperação frente ao narcotráfico}

O narcotráfico é um fenômeno essencialmente transnacional, sendo sua dinâmica ditada sobretudo pelas leis da oferta e da demanda. Como tal, associa-se e nutre-se das transformações de ordem política e econômica que, sobretudo a partir dos anos setenta, levaram à intensificação do fluxo de bens, capitais e de pessoas através das fronteiras nacionais. O fim da confrontação bipolar teve como uma de suas conseqüências a modificação das percepções de ameaças por parte das grandes potências, e em particular dos Estados Unidos, como também por parte de países em desenvolvimento. Em face do esvaziamento de ameaças tradicionais à segurança e do avanço do narcotráfico em praticamente todos os continentes, o mesmo passou a ser percebido como uma das mais importantes ameaças à segurança dos Estados, tendo se inserido na agenda política do continente americano de forma intensa, em razão de nele se situarem os principais produtores e o maior mercado de cocaína, além de outras drogas ilegais.

Acrescem-se a isso a crescente globalização da produção e dos mercados e a liberalização do fluxo de bens, serviços e fatores de produção, ou seja, a formação de áreas economicamente integradas. Tais fenômenos, quer pela proliferação de canais por onde tanto o tráfico como as operações de lavagem de dinheiro podem ocorrer, quer pela porosidade das fronteiras que 
deles decorrem, geram um ambiente propício para a intensificação de atividades econômicas e para os negócios internacionais, inclusive os ilícitos ${ }^{19}$, ao mesmo tempo em que dificultam as ações que visam o seu enfrentamento como, por exemplo, aquelas voltadas para o controle aduaneiro e policial. Este fato tornase particularmente mais grave em países como o Brasil, onde, em virtude da extensão e dificuldade de acesso às áreas de fronteira, a própria presença do Estado é dificultada.

Ao mesmo tempo, a persistência de um quadro de pobreza generalizada e os deslocamentos sociais resultantes das transformações no plano da produção internacional e que afetam as economias tanto de países industrializados como em desenvolvimento, traduzindo-se em elevação dos índices de desemprego e em empobrecimento de vários segmentos sociais, constituem um fator extremamente favorável à expansão e à diversificação do comércio de drogas ilícitas ${ }^{20}$.

Diante desses fatores, a cooperação internacional torna-se um imperativo para o controle sobre a produção, o comércio e o consumo de drogas ilegais. Esforços nesse sentido vêm sendo empreendidos desde 1909, quando se celebrou em Shangai a primeira conferência internacional para fiscalizar o tráfico de ópio. A questão foi também tratada no âmbito da Sociedade das Nações, tendo sido objeto de três convenções internacionais entre os anos vinte e trinta. A partir de 1946, a cooperação internacional passou a ocorrer sob a égide da Organização das Nações Unidas que logrou unificar em 1961, através da Convenção Única de Estupefacientes, a maioria dosinstrumentosinternacionais de controle e fiscalização.

O aumento do consumo e do tráfico de drogas ilícitas nos anos setenta levou à formulação, entre 1982 e 1986, de uma Estratégia Internacional para a Fiscalização do Uso Indevido de Drogas. No entanto, o principal instrumento de cooperação multilateral para o combate ao tráfico de drogas resulta das conferências celebradas em Viena em 1987 e 1988: a Convenção das Nações Unidas contra o Tráfico Ilícito de Estupefacientes e Substâncias Psicotrópicas. Esta Convenção abarca os mais variados aspectos do combate às drogas ao mesmo tempo em que estabelece compromissos em termos de ações preventivas, fiscalização e controle, repressão, e outras formas de cooperação e assistência internacional. A mesma constitui, no presente, a principal referência para a cooperação nos planos regionais e subregionais bem como para a formulação de políticas nacionais antidrogas. 
A dimensão continental da cooperação: a centralidade da política antidrogas norte-americana

A cooperação internacional frente à questão das drogas no continente americano não pode ser adequadamente analisada sem se considerar a evolução das estratégias norte-americanas e sua influência sobre as posições e definições de políticas dos demais países do continente. Esta influência manifesta-se não apenas por meio dos esforços empreendidos unilateralmente pelos Estados Unidos no sentido de conter a oferta de drogas através de medidas repressivas levadas a efeito sobretudo nos países produtores. Manifesta-se também na forma com que as autoridades norte-americanas definem prioridades quanto aos objetivos e à alocação dos recursos destinados ao combate ao narcotráfico mediante avaliações sobre as tendências quanto ao consumo, tráfico e efetividade das ações de repressão e de controle de demanda tanto em seu território como nos demais países. O alto grau de dependência das organizações multilaterais, tanto de alcance global como regional, e dos próprios países individualmente em relaçãoà ajuda dos Estados Unidos para a implementação de suas respectivas estratégias de combate ao narcotráfico as tornam suscetíveis à influência e injunções da própria política norte-americana.

Além disso, na medida em que impacta diretamente o maior mercado para as drogas produzidas na América Latina, e que incide sobre a produção e as condições do tráfico nos países produtores e de trânsito, a política antidrogas norte-americana repercute, de modo inevitável, nas estratégias dos grandes cartéis e dos grupos a eles associados, induzindo assim mudanças no contexto e no próprio modus operandi destes mesmos grupos. A percepção destas mudanças, por sua vez, condicionam a formulação de respostas em nível político e operativo em cada país.

Por fim, há que se considerar as reações (favoráveis ou desfavoráveis) dos países latino-americanos à política antidrogas implementada pelos Estados Unidos como um importante aspecto na determinação de suas próprias políticas neste campo, bem como das possibilidades e formas de cooperação internacional em âmbito bilateral e regional. Essas reações não são uniformes: os países andinos, principais produtores de coca, foram alvo preferencial de ações norteamericanas destinadas a reduzir a produção, inclusive com o envolvimento direto de efetivos militares; ainda de forma reticente, estes se viram praticamente instados a alinharem-se às diretrizes políticas emanadas do Departamento de Estado e executadas sobretudo pela DEA. Os países identificados como países de trânsito, como o Brasil, vêm logrando manter maior autonomia na formulação 
de suas políticas, ainda que também sujeitos a fortes pressões para maior comprometimento com a repressão ao tráfico nos moldes pretendidos por Washington.

Por essas razões, faz-se necessário discorrer, ainda que sucintamente, sobre a evolução da política antidrogas dos Estados Unidos a fim de analisar como a cooperação no âmbito do continente americano eno próprio Cone Sul vem sendo empreendida.

\section{A política antidrogas na administração Reagan}

O rápido aumento do consumo de drogas nos Estados Unidos verificado no início dos anos oitenta e o agravamento de problemas sociais dele decorrente levaram a sociedade americana a pressionar o governo a adotar medidas mais rigorosas de repressão e controle sobre o tráfico e uso de drogas. AAdministração Reagan, recém instaurada e comprometida com a prosperidade econômica internamente e com o revigoramento da hegemonia e com a reafirmação do poder norte-americano no plano internacional, adotou uma estratégia que contemplava, em última instância, reduzir a oferta de drogas através de medidas de repressão ao tráfico no plano doméstico e à produção, ao processamento e ao tráfico no exterior, configurando o que o próprio Presidente denominou de "guerra às drogas”21. No plano doméstico, a campanha antidrogas desencadeada por Reagan, teve respaldo do Congresso, que aprovou as propostas do Executivo de uma legislação mais rigorosa e aumento dos recursos a serem destinados ao combate às drogas; em sua própria esfera, o governo intensificou a participação das forças militares em programas de interdição e apreensão de drogas, estes também revigorados. A Lei Contra o Abuso de Drogas (The US Anti-DrugAbuse Act) promulgada em 1986 terminou por definir a estratégia que se delineara desde 1984, e que apesar do seu nome, orientou-se muito mais para a redução da oferta de drogas destinadas aos Estados Unidos e não propriamente para a prevenção do abuso no plano doméstico.

Portanto, foi no plano externo, e mais especificamente na repressão à produção e ao tráfico internacional de drogas, que a política norte-americana se desenvolveu a partir de então com maior vigor. Sinalizando a prioridade e o enfoque a ser dispensado ao tema em um contexto de emergência de novas ameaças, o comércio internacional de drogas passou a ser considerado uma questão de segurança nacional dos Estados Unidos. Em conseqüência, as forças militares e os órgãos de inteligência foram comprometidos de forma direta com o combate ao narcotráfico. Sob orientação do Departamento de Estado, a 
assistência militar e a ajuda financeira aos países produtores para a erradicação de cultivos e para a adoção de medidas coercitivas também em países de trânsito foram intensificadas ${ }^{22}$. Do mesmo modo, intensificaram-se as pressões diplomáticas para que estes mesmos países fossem cooperativos com os Estados Unidos em sua estratégia frente às drogas. Tais pressões com freqüência se fizeram acompanhar da ameaça de aplicação de sanções econômicas àqueles países que não adotassem medidas de repressão ao narcotráfico consideradas congruentes com os esforços norte-americanos.

\section{A estratégia Bush}

Embora tivesse logrado relativo êxito no que respeita ao número e volume de apreensões de drogas e ao número de prisões de traficantes tanto interna quanto externamente, os resultados de tal política mostraram-se muito aquém do desejado e do necessário para reverter o avanço do narcotráfico de modo geral. Pelo contrário, a percepção do seu agravamento e do fracasso da política adotada na Administração Reagan ${ }^{23}$ levou, já na Administração Bush, ao recrudescimento da política antidrogas nos Estados Unidos e à promulgação de uma nova Lei Anti-Abuso de Drogas ao final de 1988, prevendo medidas mais agressivas para conter o tráfico interna e externamente e instando a maior cooperação dos Estados Unidos com outros governos e com organismos como a Organização das Nações Unidas (ONU) e a Organização dos Estados Americanos (OEA), visando uma efetiva redução da oferta de drogas e apoiando a eventual constituição de uma força multinacional para combater o narcotráfico no Hemisfério. No plano doméstico, a nova lei introduziu penas bastante severas para o tráfico, para crimes associados ao mesmo e para traficantes reincidentes.

À essa lei seguiu-se o anúncio, em setembro de 1989, da Estratégia para o Controle Nacional de Drogas, estabelecendo, dentre suas prioridades internacionais, o desmantelamento dos cartéis de drogas, a redução da oferta de cocaína mediante o isolamento das principais áreas de cultivo da coca, a ajuda econômica, militar e policial aos países andinos, a repressão ao tráfico de precursores químicos e a intensificação dos esforços de interceptação da droga antes de sua entrada nos Estados Unidos ${ }^{24}$. A estratégia a partir de então implementada não alterou substancialmente o enfoque de reprimir a oferta de drogas. Segundo Bruce Bagley, "the new legislation did not abandon existing US supply-side programs abroad but, rather, expanded them while simoustaneously opening a second front directed at reducing demand in the United States"25; 
assim, a despeito das crescente importância que passou a ser conferida desde então à redução da demanda interna, intensificaram-se as ações voltadas para a contenção da oferta de drogas, que se manteve como principal objetivo a ser buscado no plano internacional. A militarização do combate às drogas emergiu, se não como o mais importante, seguramente o mais controvertido aspecto da política norte-americana, particularmente por seus requerimentos em termos de recursos como por suas repercussões e desdobramentos junto aos países latinoamericanos.

Ao reforçar a idéia de que o narcotráfico representa uma ameaça à segurança dos Estados Unidos, a nova estratégia associou o seu enfrentamento ao de outras ameaças aos interesses de segurança no continente, como o terrorismo e as guerrilhas, segundo a interpretação então corrente de que tais fenômenos não se manifestavam isoladamente do narcotráfico, do que deveria resultar ações abrangentes para o seu enfrentamento. Expressões como "narcoterrorismo" e "narcoguerrilha" foram incorporadas aos discursos e às análises oficiais e da própria mídia sobre o fenômeno do narcotráfico na América Latina a partir de então. Além disso, o enfrentamento ao narcotráfico não estava, para os formuladores de política, dissociado do interesse em fortalecer os regimes democráticos recém instaurados na América Latina, uma vez que o mesmo requeria o aperfeiçoamento de instituições democráticas e do controle civil sobre os militares ${ }^{26}$. Também não se dissociava da promoção de reformas econômicas entendidas como necessárias para promover alternativas de desenvolvimento econômico em países cujas economias estavam fortemente afetadas pela economia do narcotráfico, o que levou o governo Bush a anunciar, em maio de 1990, a Estratégia para os Países Andinos. Esta iniciativa consistia na oferta, aos países andinos, de recursos para investimentos e para apoiar políticas de reconversão em áreas de cultivo de coca, além de tratamento favorecido para o pagamento de dívida oficial daqueles com os Estados Unidos. O pressuposto fundamental era o de que, através do incentivo ao desenvolvimento de alternativas econômicas, tais países lograriam reduzir os atrativos do cultivo da coca e do comércio de drogas ilícitas e, conseqüentemente, o impacto do narcotráfico em geral em suas economias e nas sociedades e, em última instância, reduzindo a oferta de drogas dentro dos Estados Unidos.

À medida em que, na concepção norte-americana, o enfrentamento ao narcotráfico também associava-se aos interesses de segurança e a formas de violência política presentes em alguns países andinos, notadamente Peru e Colômbia, à consolidação democrática e à promoção de reformas econômicas, seu tratamento tornou-se muito politizado e suscitou da parte dos países latino- 
americanos reações que marcaram uma postura cautelosa e crítica frente ao enfoque que orientava as ações e a cooperação com os Estados Unidos nesta área. Apesar do aumento pelos Estados Unidos da ajuda financeira e dos recursos destinados ao combate ao narcotráfico, temas como o engajamento das Forças Armadas, a presença e atuação das forças norte-americanas em seus territórios, o estabelecimento de força multinacional para combater o narcotráfico na região, a erradicação de cultivos de coca e o enfoque predominantemente repressivo que orientava a política norte-americana constituíram focos de divergência entre os países latino-americanos e os Estados Unidos e que permearam as iniciativas de concertação regional a partir de então desencadeadas.

De Cartagena a San Antonio: a busca de convergência e os impasses com os países latino-americanos

Essas divergências tornaram-se mais visíveis após a Cúpula de Cartagena, realizada em fevereiro de 1990, da qual participaram os Presidentes dos países andinos e o Presidente George Bush para tratar da cooperação no combate ao narcotráfico. O documento subscrito nessa ocasião representa um importante marco na luta contra as drogas no continente americano. Reflete, em seu conjunto, uma visão tendente à cooperação em bases multilaterais, tal como propugnado pelos países latino-americanos, e uma visão mais equilibrada em termos da equação demanda-oferta de drogas do que a estratégia norteamericana, até então fortemente centrada na redução da oferta. Nele são enunciados os princípios norteadores da cooperação regional e das ações frente ao narcotráfico em todas as suas dimensões. Consagra o princípio da coresponsabilidade, pelo qual "os esforços contra as drogas devem tomar em conta a redução da demanda, o consumo e a oferta, e compreender entendimentos sobre a cooperação econômica, o desenvolvimento alternativo, o estímulo ao comércio e aos investimentos, assim como sobre a luta contra o tráfico de drogas ilícitas e as iniciativas diplomáticas e de opinião pública”27 , ademais do respeito à soberania, ao ordenamento jurídico e à integridade territorial dos países. Também identifica os campos de ação na luta contra as drogas, envolvendo ${ }^{28}$ : a) medidas preventivas conducentes à redução da demanda; b) ações de controle e repressão do cultivo ilegal, da elaboração e da comercialização de drogas ilícitas; c) o controle de substâncias químicas essenciais para a produção de drogas ilícitas; d) a desapropriação e repartição dos lucros e bens obtidos com a produção e o comércio de drogas ilícitas; e) o emprego coordenado de 
organismos policiais, militares, fiscais e judiciais; f) medidas para obter a redução efetiva do cultivo ilegal da coca.

Em vista do relevo que procuravam imprimir à cooperação multilateral e a um tratamento mais abrangente que a contenção da oferta por meios repressivos, os países latino-americanos, e mais particularmente Bolívia, Peru e Colômbia, logo em seguida à Cúpula de Cartagena, passaram a manifestar seu descontentamento com a unilateralidade da política norte-americana, com as condicionalidades impostas ao acesso à ajuda financeira e com o montante dos recursos disponíveis para os programas de assistência econômica para a erradicação do cultivo ilegal de coca. Manifestavam, com o apoio dos demais governos, preocupação com a ênfase prestada às medidas repressivas, o que conduziria ao envolvimento das Forças Armadas, expondo-as à corrupção eabrindo possibilidades de desequilíbrios cívico-militares, de escalada de violência e de abuso aos direitos humanos $^{29}$ em um contexto ainda marcado por fragilidades institucionais em diversos campos.

Apesar destas reações desfavoráveis e das divergências mencionadas, os Estados Unidos não alteraram a essência de sua política antidrogas para a América Latina e seguiram, no Governo Bush, insistindo em promover a cooperação internacional centrada em ações repressivas. Em uma segunda Conferência de Cúpula realizada em San Antonio, Texas, essa orientação é reafirmada. Nela os Estados Unidos propuseram a criação de mecanismos de coordenação regional: conferências para proceder a avaliações regulares dos esforços empreendidos no enfrentamento ao narcotráfico e um grupo de ação regional, de caráter operativos.

Os governos latino-americanos se mostraram favoráveis a um mecanismo de coordenação regional, uma vez que o mesmo poderia contrabalançar o tratamento unilateral dispensado pelos Estados Unidos à cooperação frente a questão das drogas. Ao mesmo tempo, não foram muito receptivos à criação de um grupo de ação também por temerem que o mesmo viesse a permitir o revigoramento de ações intervencionistas, tal como ocorrido no Panamá em janeiro de 1990, em detrimento do respeito às soberanias nacionais e da integridade territorial. Reafirmaram também seu entendimento manifestado desde a Cúpula de Cartagena, de que a repressão ao tráfico de drogas ilícitas é uma questão de caráter essencialmente policial, podendo as Forças Armadas dele tomar parte segundo o interesse e o ordenamento jurídico de cada país. De tal modo, essas propostas não prosperaram levando ao esvaziamento destes esforços. Simultaneamente, e apesar dos avanços logrados em termos de interceptação de drogas destinadas aos Estados Unidos, aumentaram as pressões sobre o governo 
norte-americano no sentido de atuar mais intensamente no plano doméstico em face do aumento, no plano interno, do consumo de drogas e dos crimes relacionados ao uso e tráfico de entorpecentes.

\section{A política antidrogas da administração Clinton}

No primeiro mandato do Presidente William P. Clinton(01/93a 01/97), a política antidrogas dos Estados Unidos consolidou a tendência já observada desde o Governo Bush de centrar esforços no plano doméstico, sobretudo na implementação de medidas jurídicas mais estritas, na redução da demanda e na interdição e repressão do tráfico; isso, no entanto, não significou menor ênfase às ações e à cooperação no plano internacional. Ao contrário, observou-se, entre 1993 e 1996, o aumento, em termos absolutos, dos recursos destinados aos programas internacionais e o fortalecimento dos esforços de repressão, que se mantiveram como o mais importante aspecto da política antidrogas norte-americana no plano externo. Por outro lado, a participação dos programas internacionais no orçamento federal para o controle de drogas manteve-se em torno $2,5 \%$, como se verá em seguida.

Observa-se, nos últimos anos, portanto, um esforço por parte dos Estados Unidos de adotar um enfoque mais equilibrado eintegral em sua política antidrogas que contemple a redução do consumo, a repressão às organizações e cartéis que comandam o narcotráfico, a erradicação de cultivos, a prevenção e reabilitação, o aperfeiçoamento e fortalecimento de mecanismos judiciais para fazer frente ao tráfico e aos delitos a elerelacionados ${ }^{30}$. No que se refere à estratégia internacional para o combate às drogas, quatro aspectos centrais foram destacados pelo PresidenteClinton aoanunciá-la em fevereiro de $1994^{31}$ : a) apoio ao desenvolvimento de instituições democráticas para a ação contra as drogas; b) apoio a programas dedesenvolvimento sustentável para o fortalecimento das economias dos principais países produtores de drogas; c) a cooperação com organismos internacionais e o envolvimento de instituições financeiras internacionais no enfrentamento às drogas; d) o estímulo da melhoria dos esforços de aplicação de leis e fortalecimento dos controles sobre precursores químicos, fluxos financeiros e dos procedimentos de extradição a fim de enfraquecer e desmantelar as organizações do narcotráfico e prender e sentenciar seus líderes.

A tentativa de uma política antidrogas mais abrangente está refletida na própria evolução do orçamento federal a ela destinado: na Administração Bush (1988/92), este orçamento aumentou de US \$ 4.7 bilhões para US\$11.9 bilhões, com crescente participação dos programas judiciais, de redução de demanda e 
para a interdição de drogas ${ }^{32}$. No primeiro mandato do Presidente Clinton, o orçamento alcançou US\$ 13.8 bilhões. Para o ano fiscal de 1997, os Estados Unidos gastarão US \$ 15.1 bilhões no controle de drogas. Deste total, US\$13.3 bilhões, ou seja, 88\% de todo o orçamento, será empregado em ações e programas domésticos voltados para a aplicação da lei (8.3 bilhões) e redução da demanda (US\$ 5 bilhões). Dos US \$1.8 bilhões restantes, US\$1.4 bilhão será destinado aos esforços de apreensão e US $\$ 401$ milhões, ou seja, apenas 2,6\%, para programas internacionais ${ }^{33}$.

Dos cinco objetivos estratégicos da atual política antidrogas norteamericana, três estão voltados prioritariamente para questões domésticas: motivar os jovens a rejeitar o uso de drogas ilegais e o abuso de drogas, reduzir o crime e a violência relacionada às drogas e reduzir os custos decorrentes do uso de drogas ilegais e da violência a ele associada ${ }^{34}$.

Os dois objetivos restantes dizem respeito à dimensão internacional e à contenção da oferta de drogas através da interdição e da repressão à produção tanto doméstica quanto estrangeira. Como afirmado anteriormente, a formulação dos objetivos estratégicos dos Estados Unidos neste campo e as ações concebidas para o atingimento dos mesmos representam um importante condicionante da própria cooperação em âmbito hemisférico, regional e bilateral frente à questão das drogas e ao narcotráfico em particular. Em relação às ações em áreas de fronteiras, presta-se ênfase à identificação de possibilidades de melhorar a eficiência na aplicação de dispositivos legais para conter o tráfico, ao fortalecimento de mecanismos de intercâmbio de informações e de inteligência para evitar o tráfico por terra, água e ar e assegurar o uso de recursos de interdição em áreas de trânsito ${ }^{35}$. No que respeita à atuação sobre a oferta de drogas, destacam-se os seguintes objetivos $^{36}$ : a) desmantelamento das organizações do narcotráfico, a prisão de seus líderes e a apreensão de seus bens e das drogas em seu poder; b) erradicação de cultivos e ataque às redes de apoio ao narcotráfico (químicos, lavagem de dinheiro e transporte); c) pressão sobre países para buscar maior cooperação dos mesmos com os Estados Unidos através de diplomacia agressiva, certificação e seletividade na assistência prestada; d) fortalecimento de instituições nos países produtores e de trânsito para que os mesmos possam desenvolver políticas antidrogas mais autonomamente; e) maior uso deorganizaçõesmultilaterais para compartilhar os custos do controle internacional de narcóticos; f) reduzir a oferta e a demanda interna de drogas.

A enunciação destes objetivos evidencia a intenção dos Estados Unidos de intensificar as ações repressivas nas áreas de produção e de trânsito salientada por operativos militares no rastreamento e na interceptação de aeronaves no Peru, 
Bolívia e Colômbia, e, segundo informações de imprensa ${ }^{37}$, também em território brasileiro. Segundo o Jornal do Brasil: “Agentes americanos da DEA agem livremente no Brasil”" (09.12.95, p. 2). Segundo a denúncia, os radares instalados pela DEA nas fronteiras entre Peru e Colômbia teriam um alcance de trezentos quilômetros sobre o território brasileiro, permitindo a detecção e interceptação de aeronaves sem o conhecimento e autorização das autoridades brasileiras.

O apoio prestado ao governo da Colômbia na repressão aos cartéis colombianos $^{38}$ e na prisão de seus líderes confirma tal disposição. Evidencia também a preocupação em fazer com que os países latino-americanos comprometam maiores recursos financeiros, materiais e humanos nas ações antidrogas em seus respectivos territórios, porém de forma consonante com os interesses e prioridades estabelecidas por Washington. Percebe-se, portanto, duas vertentes distintas, e em certo sentido, contraditórias, na política norteamericana em sua dimensão internacional e com implicações significativas para a cooperação no plano regional: a primeira, manifesta-se em nível bilateral, onde, através da certificação, exercita-se a unilateralidade mediante o emprego da tradicional política do "sticks and carrots"; a segunda valoriza os canais multilaterais e os acordos internacionais como forma de legitimação, de arregimentação e de estabelecimento de critérios para avaliação da conduta de terceiros países no enfrentamento à questão das drogas.

A persistência do padrão "sticks and carrots” evidencia uma distorção da política antidrogas norte-americana à medida que a mesma direciona-se e penaliza não somente aos agentes e ao objeto do narcotráfico; penaliza também governos e sociedades que podem ver-se privadas da assistência e da possibilidade de aceder a recursos de organismos financeiros internacionais necessários para a promoção de alternativas e de projetos de desenvolvimento que podem direta ou indiretamente auxiliar no enfrentamento à produção, ao tráfico e ao consumo de drogas ilícitas ou mesmo virem a assistir a escalada da violência no contexto da "luta contra as drogas". Neste sentido, e apesar dos esforços em estabelecer um marco de cooperação com base em um entendimento comum sobre a natureza, as dimensões, as conseqüências e as estratégias de resposta ao narcotráfico no continente americano, persiste um grande potencial de divergência entre os Estados Unidos e os países latino-americanos o qual pode manifestarse em um nível mais elevado de atritos diplomáticos, como vem ocorrendo em relação à Colômbia recentemente, em detrimento da própria cooperação quer no plano bilateral como regional. Estas dificuldades podem ser atribuídas à desigual distribuição dos custos de implementação de acordos bilaterais voltados para o combate às drogas ${ }^{39} \mathrm{e}$ ao uso agressivo, pelos Estados Unidos, do processo de 
certificação e da possibilidade de suspender a assistência e de votar, em organismos financeiros multilaterais, contra a concessão de empréstimos a países cujos esforços antidrogas não sejam avaliados como condizentes com os compromissos fixados pela Convenção das Nações Unidas contra o Tráfico Ilícito de Narcóticos e de Substâncias Psicotrópicas de $1988^{40}$. Estão relacionadas também às limitações, mesmo que justificáveis, dos esforços empreendidos pelos países latino-americanos no enfrentamento da produção e do comércio de drogas ilegais e no cumprimento de seus compromissos internacionais neste campo e que conduzem à permanência de condições propícias para a expansão do consumo e do tráfico e dos fenômenos aos quais ele se associa e dos quais ele se nutre.

\section{As bases da cooperação interamericana}

Ante a impossibilidade de atuação individual e isolada por parte dos países frente a um fenômeno de natureza essencialmente transnacional como o narcotráfico, a cooperação no plano internacional, quer em bases multilaterais como bilaterais, passa a representarum imperativo, sobrepondo-se às dificuldades e aos impasses de ordem política anteriormente mencionadas. De tal modo, a elaboração de uma estratégia comum aos países americanos de enfrentamento ao narcotráfico em suas diversas dimensões, resulta de um processo de busca de convergências entre proposições norte-americanas, por um lado, e as posições sustentadas pelos países latino-americanos, as quais, mesmo não sendo uniformes, guardam, em seu conjunto, diferenças importantes em relação à política antidrogas norte-americana. Em outras palavras, a cooperação, no plano continental, frente ao narcotráfico não se estancou diante das dificuldades de compatibilizar as posições dos Estados Unidos e dos países latino-americanos quanto à ênfase e as estratégias voltadas para a redução da oferta de drogas e quanto à forma de entabular ações mais coordenadas multilateralmente. Estas dificuldades, como antes mencionado, já haviam se manifestado nas conferências de Cartagena e San Antonio, e se mostraram fortes o suficiente para impedir o estabelecimento de posições consensuais que resultassem em ações conjuntas efetivas.

Observa-se, nas discussões em distintos foros de alcance regional, a tendência de considerar o narcotráfico como um problema a ser enfrentado mediante o fortalecimento das instituições democráticas e a plena observância aos princípios jurídicos interna e internacionalmente sem, no entanto, desconsiderar que o mesmo representa uma efetiva ameaça do ponto de vista da segurança dos 
Estados individualmente e da região em seu conjunto, podendo, em conseqüência, requerer destes o uso de meios coercitivos de forma mais intensa segundo as peculiaridades de suas manifestações em cada país. Isso tem, nos foros multilaterais, permitido configurar um enfoque mais abrangente e equilibrado que aqueles apresentados no início dos anos noventa, inspirados em uma inclinação unilateral dos Estados Unidos e essencialmente pautados em ações repressivas.

Também acordaram medidas de fortalecimento dos instrumentosjurídicos para combater a lavagem de dinheiro. Foi proposta a adoção ou o fortalecimento da legislação doméstica definindo o delito da lavagem de dinheiro e estabelecendo sanções correspondentes ${ }^{41}$. Finalmente, os países participantes comprometeramse em adotar e implementar as convenções e instrumentos multilaterais e as recomendações emanadas da CICAD no sentido de fortalecer os sistemas jurídicos e intensificar a cooperação no intercâmbio de informações e de inteligência ${ }^{42}$.

Essas decisões marcaram a disposição dos países em atuar de forma coordenada e de enfrentar a questão das drogas a partir do respeito aos princípios do Direito Internacional e do fortalecimento dos instrumentos jurídicos no plano doméstico, em consonância com as posições que vinham sendo sustentadas pelos países latino-americanos. Além disso, o fato de tratar o narcotráfico de forma vinculada a outros delitos como o tráfico de precursores químicos e de armas e a lavagem de dinheiro implicava maior necessidade de cooperação e de comprometimento político no seu enfrentamento. Por fim, como importante avanço logrado na Cúpula de Miami, há que se destacar a ênfase conferida à ação dos organismos multilaterais, e particularmente da OEA, através da Comissão Interamericana para o Controle do Abuso de Drogas (CICAD). No entanto, tal posição não se fez acompanhar do necessário aumento de recursos financeiros a eles destinados ${ }^{43}$.

Os elementos centrais da estratégia hemisférica definidos na Cúpula de Miami foram objeto de discussão e detalhamento no âmbito da CICAD entre 1995 e 96, resultando em um documento aprovado em outubro de 1996, denominado “Estratégia Antidrogas no Hemisfério”. Trata-se, segundo o próprio documento, de um "esforço hemisférico no sentido de definir uma pauta para a cooperação com o caráter de recomendação, que possibilite a nossos países a adoção de um conjunto de medidas e atividades capazes de permitir, quando postas em prática, robustecer os esforços nacionais" ${ }^{44}$. O documento trata de medidas voltadas tanto para a redução da demanda como da oferta de drogas naturais e sintéticas, além de medidas de controle. No tocante à redução da demanda, dá-se ênfase à pesquisa e a programas de prevenção, tratamento, 
reabilitação e reinserção social, bem como à educação preventiva e ação comunitária como formas de gerar uma consciência social contrária ao uso de drogas. Para a redução da oferta de drogas, particularmente as naturais, priorizam-se medidas voltadas à promoção de opções econômicas "lícitas, viáveis e sustentáveis” e que, conjuntamente à aplicação da lei, possam levar à erradicação e conseqüentemente à redução da sua oferta. Percebe-se a preocupação em não explicitar medidas repressivas como parte das opções de redução da oferta, em detrimento da orientação norte-americana neste campo que enfatizava o maior envolvimento das Forças Armadas na repressão ao tráfico e na erradicação de cultivos. As medidas de repressão, no documento da CICAD, ficam reservadas apenas à produção e tráfico de drogas sintéticas ${ }^{45}$. O documento também ressalta a importância da cooperação internacional no intercâmbio de informações, arrecadação de provas e evidências, visando o desmantelamento das organizações criminosas e de suas redes de apoio, o processamento e condenação de seus líderes. Também refere-se à necessidade de estabelecer mecanismos de controle interno e regional de precursores e substâncias químicas, segundo a Convenção de Viena de 1988 e o regulamento da própria CICAD, além do controle de armas e explosivos ${ }^{46}$. O Brasil assinou o referido documento em janeiro de 1997.

Apesar dos avanços observados no plano multilateral, particularmente no sentido de inibir impulsos de atuar frente a questão das drogas através de medidas repressivas, não se pode dizer que os Estados Unidos, em particular, tenham abdicado de sua posição neste campo. É importante perceber que, simultaneamente aos trabalhos desenvolvidos no âmbito da OEA, o narcotráfico foi também objeto de discussão nas duas reuniões, dos Ministros de Defesa do continente, ocorridas em Williamsburg (outubro de 1995) e Bariloche (outubro de 1996) respectivamente e convocadas, sob a liderança norte-americana, conforme escrito anteriormente, para discutir a construção de um regime internacional de segurança nas Américas e para tratar da cooperação neste campo em face das transformações ocorridas nos cenários internacional e hemisférico. $\mathrm{O}$ fato de tais discussões ocorrerem fora do âmbito da OEA revela, para muitos, a disposição dos Estados Unidos de afirmar e legitimar sua política e interesses de segurança por outros instrumentos além dos organismos multilaterais onde, conforme antes mencionado, sobretudo a diminuição da oferta de drogas com ênfase às medidas repressivas encontra forte resistência por parte dos demais países no continente.

Adeclaração final da Conferência de Williamsburg enumera os seguintes compromissos: fortalecimento das democracias e da participação dos militares 
neste processo, submissão das Forças Armadas ao poder civil, transparência na cooperação em matéria de defesa, fixação de metas para a resolução negociada de disputas e cooperação na luta contra o narcotráfico e na participação em missões de paz. Estes pontos constituem os próprios princípios da política de segurança dos Estados Unidos para o continente, o que faz com que sejam também percebidos como um esforço de reafirmação hegemônica dos Estados Unidos ${ }^{47}$.

Nesse sentido, a referência ao narcotráfico, portanto, poderia ser interpretada simplesmente como parte do esforço dos Estados Unidos de buscar um maior envolvimento das Forças Armadas latino-americanas no enfrentamento de ameaças de natureza transnacional, particularmente o narcotráfico. No entanto, é importante considerar que a percepção do narcotráfico como ameaça à segurança nãoé exclusiva dos Estados Unidos, sendo, ao contrário, compartilhada pelos demais países do continente. As formas de enfrentá-lo, sim, é que são diferentes, segundo suas manifestações. Como a preocupação básica tanto em Williamsburg como em Bariloche foi promover a cooperação em matéria de segurança a partir dos pontos consensuais e não propriamente eliminando divergências, pouco foi possível avançar ou inovar quanto a propostas de ação de enfrentamento ao narcotráfico. No entanto, não se deve subestimar a importância do narcotráfico em ambas as reuniões, principalmente no sentido de legitimar políticas antidrogas que possam amparar-se no recurso aos instrumentos de poder, dentre os quais, e eventualmente, as Forças Armadas. ${ }^{48}$

A questão do narcotráfico vem, ao longo dos últimos anos, ganhando destaque na agenda do Grupo do Rio. No entanto, somente a partir das duasúltimas reuniões de cúpula celebradas em Quito, Equador, em setembro de 1995, e em Cochabamba, Bolívia, em setembro de 1996, os quatorze países membros definem mais claramente uma posição conjunta frente ao narcotráfico. Na IX Reunião de Cúpula deQuito, os países membros decidiram unificar suas respectivas legislações antidrogas como um passo fundamental para a concertação de suas ações nesse campo $^{49}$. Pelo fato de que tal decisão não deva ser implementada de forma imediata, a mesma tem sido entendida como uma afirmação de compromisso e de vontade política, embora a evolução nesse sentido a médio elongo prazo signifique, além disso, um poderoso elemento instrumental para a cooperação, uma vez que as diferenças entre as legislações nacionais e a ausência de mecanismos de consulta é um elemento facilitador das ações dos grupos narcotraficantes e do crime organizado em geral.

Na mesma ocasião, e refletindo em grande medida uma posição brasileira $^{50}$, o Grupo do Rio conclamou os países consumidores, e em particular os Estados Unidos, a assumir com maior clareza e determinação suas 
responsabilidades no enfrentamento ao narcotráfico, em um evidente esforço de resposta às pressões norte-americanas sobre os principais países produtores e de trânsito no sentido de instá-los a maior rigor na repressão à produção e ao tráfico de drogas.

Um ano depois, na X Reunião de Cúpula, são enunciados os princípios orientadores da ação do Grupo do Rio e, entre eles, a luta contra o narcotráfico e contra os delitos conexos (lavagem de dinheiro, tráfico de armas e de precursores químicos). Em consonância com as posições também adotadas no âmbito da OEA, a Declaração de Cochabamba alude à “plena observância do princípio da co-responsabilidade que conduza a resultados mais efetivos e que reflitam uma visão integral e equilibrada da problemática do narcotráfico"51 e reitera a importância na luta contra as drogas, que os países considerem aspectos sociais e econômicos e que promovam esforços em programas de desenvolvimento alternativo, social e regional que conduzam à melhora das condições de vida das populações afetadas.

As posições do Grupo do Rio, em resumo, não guardam diferenças significativas em relaçãoàquelas já enunciadas no âmbito da OEA. Sua importância, no entanto, reside no fato de que, por constituir-se em um foro de consulta e concertação política, o Grupo do Rio termina constituindo uma importante arena de uniformização e de solidificação de posições regionais no âmbito do continente como um todo.

\section{A cooperação no âmbito do Cone Sul}

O narcotráfico, suas implicações políticas e sócio-econômicas, é tema relativamente novo na agenda de cooperação entre os países do Cone Sul, apesar da natureza essencialmente transnacional do fenômeno e da vinculação dos referidos países notadamente no que se refere ao consumo, trânsito e à lavagem de dinheiro. A preocupação com o estabelecimento de mecanismos de cooperação entre os países do Cone Sul possui algumas razões: em primeiro lugar, a crescente importância política e econômica do narcotráfico nos planos internacional e regional, afetando países vizinhos e projetando-se na sub-região; em segundo, as mudanças sócio-econômicas ocorridas, traduzidas em maiores níveis de estabilidade macroeconômica, mas que induzem simultaneamente processos de exclusão social; em terceiro, a fragilização dos instrumentos de Estado e a inexistência de políticas efetivas e concertadas regionalmente, colocando governos e sociedades à mercê de proposições externas de políticas de resposta ao narcotráfico nem sempre convergentes com as visões, 
necessidades e possibilidades de nossos países, levando os mesmos a intensificar o diálogo político e a cooperação frente ao tema.

Em um contexto marcado pelo avanço do tráfico e do consumo de drogas, pelo conseqüente aumento de suas responsabilidades e envolvimento frente ao tema, e pelas restrições que enfrentam os países do Cone Sul em termos de recursos financeiros, materiais e humanos para fazer frente ao narcotráfico, a cooperação internacional assume particular relevância. Contudo, não apenas os aspectos acima mencionados devem ser considerados: como já mencionado, há que se tomar em conta as próprias transformações dos cenários regional e internacional para avaliar os fatores conducentes à cooperação neste campo.

Os países do Cone Sul inseriam-se, tradicionalmente, na geoeconomia do narcotráfico, sobretudo, como países de trânsito e áreas de lavagem de dinheiro. No entanto, a identificação de perfis específicos para países no tocante ao narcotráfico torna-se crescentemente imprecisa. Ainda que os países andinos sejam os principais produtores de coca, estes e os demais países da região estão envolvidos nas demais atividades do narcotráfico internacional: processamento, trânsito, consumo e lavagem de dinheiro.

A maior penetração do narcotráfico nutre-se de muitas das transformações econômicas e políticas ocorridas na sub-região como de resto em toda a América Latina: a abertura comercial intensificou o fluxo de bens e de pessoas através das fronteiras, particularmente no Cone Sul; os mercados financeiros expandiram-se e tornaram-se mais desregulamentados, permitindo maiores facilidades para as operações de lavagem de dinheiro; a estabilidade e a valorização cambial, como no Brasil e Argentina, permitem que o comércio de drogas seja feito não apenas com o uso do dólar, cujo rastreamento vem sendo realizado, mas também em outras moedas, dificultando assim a repressão aos esquemas de lavagem.

Além da abertura e estabilização econômica, da desregulamentação de mercados e dos sistemas financeiros, outro fator do qual o narcotráfico vem se beneficiando é a integração entre mercados promovida por meio de acordos bilaterais e de esquemas sub-regionais como o MERCOSUL.

No entanto, é muito importante ressaltar que, assim como os fatores antes mencionados, a integração econômica não é, em realidade, causa ou fator em si mesmo explicativo para o aumento do narcotráfico na região. Representa antes um fator interveniente e de caráter ambíguo: pode ser um complicador para os esforços de resposta dos governos ao narcotráfico na medida em que torna mais permeáveis as fronteiras acarretando o incremento dos fluxos 
econômicos, financeiros e de pessoas do que se valem os narcotraficantes; por outro lado, gera condições políticas mais favoráveis para ações concertadas e de novas iniciativas entre os governos com vistas ao combate ao tráfico e de prevenção ao abuso de drogas; propicia também maiores possibilidades de incrementar a cooperação internacional, dentro de espaços delimitados, de forma muito mais abrangente e efetiva do que em um contexto de soberanias nacionais e de esforços autocentrados.

Nos últimos seis anos, isto é, desde a criação do MERCOSUL, a questão do narcotráfico também adquiriu maior relevância na agenda regional, embora o tema não estivesse contemplado nas negociações que, desde o período de transição(1991-1994) do MERCOSUL, estiveram centradas nos temas diretamente afetos à almejada liberalização comercial. Ultrapassada esta fase, tornou-se inevitável o tratamento de temas que, por associarem-se ou decorrerem da instauração de um regime de livre-comércio entre os países, não puderam mais ser postergados. Ainda que a agenda de negociação do MERCOSUL esteja ainda fundamentalmente voltada para temas econômico-comerciais, temas de natureza política passam a ser objeto de entendimento.

Ademais, questões como o tráfico de drogas, de armas, de carros roubados, de lavagem de dinheiro e o contrabando já estavam presentes na agenda em nível bilateral entre os países membros do MERCOSUL, e mais particularmente entre Brasil e Paraguai. O bom nível de entendimento alcançado no plano político a partir de outros foros como o Grupo do Rio contribuiu também para que o tema do narcotráfico passasse a ser objeto de negociações visando ações concertadas entre os países do MERCOSUL, inicialmente em nível bilateral. Assim, Brasil e Argentina assinaram em 1995 um acordo de cooperação para o combate ao narcotráfico e a prevenção ao abuso de drogas mediante o qual ambos os países comprometiam-se conjuntamente a intensificar ações de repressão ao tráfico em áreas de fronteiras, a intercambiar informações e a promover a cooperação entre seus respectivos órgãos policiais incumbidos da repressão ao tráfico de entorpecentes. Acordos de teor semelhante foram também feitos entre Argentina, Paraguai, Uruguai e Chile, além de outros voltados para a ação contra o contrabando e lavagem de dinheiro.

Dessa forma, é possível concluir que as definições substanciais quanto à cooperação entre os países americanos frente as drogas reflete ainda uma tensão entre as posições afirmadas multilateralmente em foros regionais como a OEA e o Grupo do Rio, e mesmo em nível sub-regional, e que constituem uma base consensual e o esforço dos Estados Unidos de conquistar apoio e projetar continentalmente elementos que considera fundamentais de sua própria política 
antinarcóticos através de uma estreita vinculação da mesma com os seus interesses de segurança. Procuram assim contrabalançar a influência que seus parceiros são capazes de exercer na definição de uma política comum para o Hemisfério reafirmando suas posições unilateralmente ou exercendo capacidade de cooptação em outros foros regionais, particularmente naqueles onde a questão do narcotráfico possa ser tratada à luz dos interesses e da política de segurança.

A efetividade da cooperação neste campo associa-se, pois, à capacidade dos países em geral de estabelecer um padrão interativo e sobrepor-se às diferenças que decorrem de distintas ênfases a campos e instrumentos de ação que marcam suas respectivas políticas antidrogas; prende-se ainda à capacidade dos mesmos de viabilizar instrumentos de cooperação menos vulneráveis a ações unilaterais e às vicissitudes políticas e econômicas que a maioria dos países na América Latina enfrenta no momento. Por fim, há que considerar como elemento fundamental o gradual incremento da convergência entre as políticas e legislações nacionais que já se observa no presente.

\section{Conclusões}

Dados, informações e observações que acabam de ser apresentados são parte de temática extremamente complexa e difícil de ser trabalhada. Tanto a sociologia, a economia, a religião, o direito, a filosofia, a história quanto o estudo das Relações Internacionais juntam-se para o esclarecimento de fenômenos transnacionais relacionados com as drogas.

Este trabalho tentou entrar nas dimensões do universo do narcotráfico, exemplificando parte de suas estruturas e ocorrências. Procurou visualizar a corrupção, as desigualdades, as ambições e as injustiças que têm empurrado segmentos sociais para o abismo do narcotráfico. Nesta busca acabou-se por defrontar a questão do Estado.

A tentativa de explicar fenômenos importantes e graves para a sociedade, como os relacionados às drogas, se não foi alcançada no seu todo pelo menos serviu para indicar que o narcotráfico émais que simples categoria de análise. Ele é verdadeiro desafio às ciências sociais, uma dor de cabeça no debate interparadigmático, colocando dúvidas sobre a interpretação realista centrada na força, no poder e na capacidade reguladora do Estado.

Sendo também o narcotráfico fenômeno que nada à vontade nas águas da globalização, sua análise pede caracterizações e interpretações. Esta é a razão 
pela qual este texto se prendeu a aspectos pragmáticos, detendo-se em fatos, tendências e perspectivas do processo de expansão das drogas do Brasil.

Maio de 1997

\section{Notas}

1 Texto elaborado no âmbito da pesquisa "Dimensões e Características Sociológicas do Narcotráfico no Brasil” patrocinada pelo Conselho Nacional de Desenvolvimento Científico e Tecnológico (CNPq) e coordenada pelo Prof. Argemiro Procópio Filho.

2 Lei 6368/76, de 21 de outubro de 1976, que dispõe sobre medidas de prevenção e repressão ao tráfico ilícito e uso indevido de substâncias entorpecentes. Decreto $\mathrm{n}^{0}$ 78.992, de 21 de dezembro de 1976, que regulamenta a Lei ${ }^{\circ} 6368$, de 21 de outubro de 1976. Decreto n ${ }^{\circ} 85.110$, de 2 de setembro de 1980, que institui o Sistema Nacional de Prevenção, Fiscalização e Repressão de Entorpecentes e cria o CONFEN como órgão central incumbido de formular e coordenar a política nacional de entorpecentes. Lei 7.560, de 19 de dezembro de 1986, que cria o Fundo de Prevenção, Recuperação e Combate às Drogas de Abuso (FUNCAB), no âmbito do CONFEN. Decreto ${ }^{\circ} 95.650$, de 19 de janeiro de 1988, que regulamenta o FUNCAB. Decreto 99.244, de 10 de maio de 1990, que reformula a estrutura institucional e política do CONFEN. Lei ${ }^{\circ}$ 8.257, de 26 de novembro de 1991, que dispõe sobre expropriação das glebas nas quais se localizam culturas ilegais e plantas psicotrópicas. Lei $n^{\circ}$ 8.764, de 20 de dezembro de 1993, que cria a Secretaria Nacional de Entorpecentes.

3 O principal meio de lavagem do dinheiro do crime organizado é o sistema financeiro nacional e transnacional. Isto tem levado o governo brasileiro a criar obstáculos institucionais para essa prática, uma vez que o Brasil entrou no esquema internacional de lavagem do dinheiro. Segundo relatório da Comissão Especial de Estudos sobre o Sistema Financeiro, presidida pelo Chefe da Casa Civil, Clóvis Carvalho, de R \$3,480 trilhões que circulam no sistema financeiro do país, R \$ 490 bilhões têm origem suspeita. Como se pode deduzir, o Brasil ainda não faz sombra a países como Suíça, Luxemburgo e aos paraísos fiscais do Caribe, porém, a cada dia cresce a sua projeção no setor, uma vez que a lavagem de dinheiro no Brasil abrange áreas econômicas de amplo espectro, que vão da pecuária até o setor de serviços, entre outras.

4 ZALUAR, Alba (Org.). Drogas e cidadania: repressão ou redução de riscos? São Paulo: Brasiliense, 1994.

5 ZALUAR, Alba. O condomínio do diabo. Rio de Janeiro: Revan/UFRJ,1994; ALBA, Zaluar. Da revolta ao crime S.A. São Paulo: Editora Moderna, 1996; VELLOSO, João Paulo dos Reis (org.). Governabilidade, sistema político e 
violência urbana. Rio de Janeiro: José Olympio Editora, 1994. ASTRO, Iná Elias et alli. Brasil: questões atuais de reorganização do território. São Paulo: Bertrand Brasil, 1996.

6 A inoperância dos tratados multilaterais e bilaterais leva a crer que, em muitos casos, foram assinados mais para dar respostas às pressões internacionais do que resultado concreto de efetiva vontade política nacional para o combate ao narcotráfico.

$7 \quad$ Dados extraídos do $3^{\circ}$ Levantamento sobre o uso de drogas entre adolescentes de $1^{\circ}$ e $2^{\circ}$ Graus da rede estadual em dez capitais brasileiras (Belém, Belo Horizonte, Brasília, Curitiba, Porto Alegre, Recife, Rio de Janeiro, Salvador e São Paulo), realizado pelo CEBRID (Centro Brasileiro de Informação sobre Drogas e Psicotrópicos). CEBRID-Escola Paulista de Medicina. $3^{\circ}$ Levantamento sobre o uso de drogas entre adolescentes de $1^{\circ}$ e $2^{\circ}$ Graus da Rede Estadual. São Paulo, 1993.

8 CONFEN. PANAD-Programa de ação nacional antidrogas. Brasília: Ministério da Justiça, 1996.

9 CEBRID-Escola Paulista de Medicina, op. cit.

10 DRE (Departamento de Repressão às Drogas) - Polícia Federal.

11 Veja, 8/9/93

12 OGlobo, 14.5 .95 , p. 8; 15/5/95, p. 5.

13 GEFFRAY, Christian. "Efeitos sociais, econômicos e políticos da penetração do narcotráfico na Amazônia brasileira”. Relatório de Atividades № 2. Fevereiro de 1996, ORSTOM/CNPq.

14 Entre os nomes atualmente identificados como grandes traficantes ligados à máfia estão Rocco Morabitto, ligado à la N'draghetta, e quem se supõe ter montado uma rede financeira para operar o narcotráfico em São Paulo; Antonio Bardelino, da máfia siciliana e se supõe estar na Bahia. Este foi sócio de empresa de exportação peruana que traficava drogas do Peru e Brasil para a Itália. Os irmãos Giuseppe Cuntrera e Paolo Cuntrera com seus primos, Gaspare e Pasquale Cuntrera, representam a Cosa Nostra no Brasil e Venezuela e são proprietários de empresas em vários Estados, incluindo navegacão, agropecuária, hotéis e restaurantes. Esta infra-estrutura, supõe-se, serve para lavar dinheiro do tráfico. Os irmãos Bruno y Renato Torsi, ligados à Camorra, podem estar em Pernambuco ou no Ceará; Pasquale Raffaele Graziani, um dos grandes chefes da Nuova Famiglia, segmento disssidente da Camorra, e Giuseppe Castoro que acredita-se estar vivendo em Mato Grosso, de onde organiza o tráfico de cocaína da Colômbia para a Holanda e Itália.

15 O Globo, $14 / 5 / 95$, p. $8 ; 15 / 5 / 95$, p. 5.

16 O trabalho de avisar ao comando a chegada de estranhos à zona de tráfico é realizado por "olheiros", que o fazem de viva-voz ou utilizando sinais. No livro Comando Vermelho, Carlos Amorim conta a história de uma criança que trabalha para o tráfico de drogas empinando uma pipa: de acordo à movimentação do papagaio, ele passa uma mensagem diferente. 
18 PROCÓPIO, Argemiro: Amazônia: em nome do padre, da posse, do poder e do domínio santo. Humanidades, Brasília-DF, 1988.

19 FLYNN, Stephen. World Wide Drugs Scourge: The Expanding Trade in Ilicit Drugs. The Brookings Review, winter 1993, pp. 6-7.

20 HARDINGHAUS, Nicolás H. The Development of the International Drugs Trade. Economics, vol 53, 1996, pp. 76-77.

21 BAGLEY, Bruce M. After San Antonio, Journal of Interamerican Studies and World Affairs, (34:3), p. 2.

22 CEPAL (1996). Significación económica y social de la producción, tráfico y consumo de drogas, p. 85.

23 BAGLEY, Bruce M., op.cit., p. 3.

24 US Departament of State. The National Drug Control Strategy. 1989.

25 BAGLEY, Bruce M., op. cit., p. 4.

26 O então Secretário Adjunto Para Assuntos de Narcóticos, Melvin Levitsky, em pronunciamento perante o Subcomitê de Assuntos do Hemisfério do Comitê de Relações Exteriores da Câmara dos Representantes, ao abordar o tema da militarização do combate ao narcotráfico, afirmou que "o envolvimento dos exércitos destes países, como em nosso próprio país, pode constituir um recurso significativo na guerra contra as drogas se estiver coordenado e dirigido apropriadamente pelas autoridades civis”. CEPAL (1996), op. cit., pp. 90-91.

27 United States Information Service. (Press Release) "Declaração de Cartagena". Fevereiro de 1990.

28 CEPAL (1996), op. cit., p. 99.

29 Estas posições foram defendidas por oficiais militares, diplomatas e expertos latinoamericanos tanto em conversações bilaterais com os Estados Unidos como também em foros, como nas reuniões de ministros de defesa do continente, realizadas em Williamsburg e Bariloche em 1995 e 1996 respectivamente e em diversos foros acadêmicos.

30 Junta Andina de Juristas. Lucha antidrogas y política para el siglo XXI, Narcotráfico al dia, pp. 4-5.

31 US Department of State. US Department of State Dispatch, vol. 5, n. 8, pp. 89-90.

32 Office of National Drug Control Policy. US Federal Drug Control Budget 19881992.

33 The White House. The National Drug Control Strategy: 1996, pp. 35-37.

34 Idem, pp. 20-21.

35 Idem, p. 21.

36 Idem, p. 21.

37 Jornal do Brasil. "Agentes americanos da DEA agem livremente no Brasil”. 09/12/95, p. 2. Segundo a denúncia, os radares instalados pela DEA nas fronteiras entre Peru e Colômbia teriam um alcance de trezentos quilômetros sobre o território 
brasileiro, permitindo a detecção e interceptação de aeronaves sem o conhecimento e autorização das autoridades brasileiras.

38 Em outubro de 1995, pela primeira vez, o Presidente dos Estados Unidos usou a autoridade que lhe é conferida pelo International Emergency Economic Powers Act para determinar a identificação dos líderes e das companhias ligadas ao Cartel de Cali e o bloqueio de seus bens nos Estados Unidos e para proibir que indivíduos e empresas norte-americanas realizassem qualquer operação comercial com tais líderes e companhias.

39 Segundo a Cepal, esta diferença relativa aos custos da implementação de acordos bilaterais se traduziu, no caso colombiano, em violência, seqüestros, mortes e instabilidade das instituições democráticas; para a Bolívia e Peru, se relacionaram a dificuldades em suas políticas externas e em prejuízos em termos de imagem internacional. Cepal (1996), pp. 105-106.

40 O processo de certificação anual é realizado entre os meses de janeiro e maio.

41 Organización de los Estados Americanos (1995). Seguridad hemisferica y lucha contra el narcotrafico, pp. 6-7.

42 United States Information Service. Cúpula das Américas. Ponto de Vista de Washington, 08/12/94.

43 Os Estados Unidos destinarão US\$ 401 milhões para programas internacionais antidrogas, o que corresponde a apenas 3\% do orçamento destinado a este fim.

44 Comissão Interamericana para o Controle doAbuso de Drogas .Estratégia antidrogas no hemisfério, p. 17.

45 Idem, p. 19.

46 Idem, pp. 20-21.

47 Aravena (1996). Williamsburg: un giro en las relaciones hemisfericas de seguridad? Seguridad estrategica regional en el 2000, nº 9, pp. 40-41.

48 Segundo Aravena (op. cit., p. 42), reuniões como a de Williamsburg representam muito mais um exercício de diplomacia de cúpula que de diplomacia multilateral: no primeiro caso, o peso das assimetrias se expressa de maneira evidente de acordo com o peso do poder de cada um dos países; no segundo, há a reafirmação dos direitos dos Estados mais fracos, assegurando-lhes um espaço de participação e decisão.

49 Grupo do Rio. Declaração de Quito, 05/09/95.

50 Folha de São Paulo. “Países da AL unificam leis sobre o tráfico”. 06/09/95, p. (1)11.

51 Grupo do Rio. Declaração de Cochabamba, 04/09/96.

\section{Resumo}

Este trabalho estuda as dimensões do universo do narcotráfico, exemplificando parte de suas estruturas e ocorrências. Além disso, vai analisar o 
narcotráfico em suas mais importantes tendências e manifestações na sociedade brasileira, e identificar as principais formas de sua vinculação ao narcotráfico internacional.

\section{Abstract}

This article analyses the world dimensions of narco-traffic, exemplifying parts of its structure and incidence. Besides, it studies the narco-traffic in its most important trends and manifestations in the Brazilian society, and identify the main ways of its links to international traffic.

Palavras chaves: Brasil. Narcotráfico. Política antidrogas.

Key-words: Brazil. Narcotics traffic. Antidrugs policy. 